\title{
The Good Cheat: Benevolence and the Justification of Collective Cheating
}

\author{
Caroline Pulfrey, Kevin Durussel, and Fabrizio Butera \\ University of Lausanne
}

\begin{abstract}
"Sharing is caring" the old adage goes, with its implied message that both are morally desirable. But what if it's test answers that students are sharing with their friends? Integrating values, cheating, and in-group bias theory, we hypothesize that adherence to group-loyalty benevolence values-considered as some of the most moral values - positively predicts the acceptance of collective cheating, that is students cheating together with in-group peers, when competition is salient. Operationalizing competition in three different ways we test this in four studies. In Study 1, adherence to benevolence values predicted positive attitudes toward collective but not individual cheating among students presented (vs. not) with a portrayal of society as competitive. Study 2 revealed that, within the competitive context of an end-of-year exam, adherence to benevolence values positively predicted moral disengagement toward collective cheating but negatively predicted individual cheating. Study 3 showed that valuing both being a dependable friend and attaining power and influence, predicted the acceptance of collective cheating. Finally, in Study 4, carried out with dyads of students, groups composed of students who knew each other cheated more than students composed of strangers. Furthermore, dyad adherence to power values positively predicted cheating behavior among dyads that knew (vs. did not know) each other. These results signal that group loyalty can, in certain conditions, lead to justifying and engaging in collective cheating, and that the motivational underpinnings may be the moral status of benevolence values.
\end{abstract}

\section{Educational Impact and Implications Statement}

This research advances the argument that students who feel loyal to peers may reject individual cheating, but have positive attitudes toward collective cheating and engage in collective cheating behavior, in other words, group-based, cheating carried out with and for peers. This phenomenon appears in contexts in which competition or the valuing of personal power is present and suggests that we need to understand more about different types of cheating.

Keywords: values, collective cheating, benevolence, competition, moral disengagement

\begin{abstract}
"Sharing is caring" the old adage goes, with its implied message that both are morally desirable. But what if it's test answers that students are sharing? While the moral undesirability of individual cheating is made crystal clear to most students, when it comes to cheating with other students, the situation is much more ambiguous. As one of 130 Harvard seniors facing charges of cheating indignantly retorted "I was just someone who shared notes, and now I'm implicated in this" (Pérez-Pena, 2012a). This incident highlights three key issues in education. First, student cheating, defined as dishonest behavior enacted to gain an advantage or depriving someone/others of something by using unfair or deceitful methods (Oxford Dictionary, 2010), is an academic reality. Research carried out by McCabe (2005)
\end{abstract}

This article was published Online First March 19, 2018.

Caroline Pulfrey, Kevin Durussel, and Fabrizio Butera, Laboratoire de Psychologie Sociale (UNILaPS), Université de Lausanne.

This work was supported by the Swiss National Science Foundation. We thank John Antonakis for invaluable guidance in statistical analysis.

Correspondence concerning this article should be addressed to Fabrizio Butera, Laboratoire de Psychologie Sociale (UNILaPS), Université de Lausanne, Geopolis, CH 1015, Lausanne, Switzerland. E-mail: fabrizio .butera@unil.ch with over 40,000 students on 68 U.S. and Canadian campuses reveals that over $50 \%$ of students admit to having cheated. Other studies carried out at university level indicate between $52 \%$ and $66 \%$ of students cheating (Bernardi et al., 2004; Hrabak et al., 2004; Rettinger, Jordan, \& Peschiera, 2004). Second, cheating can take multiple forms and is not always an individual activity. A number of cheating scandals involve students engaging in collaborative dishonesty (Chapman \& Monahan, 2012; Finder, 2007; Pérez-Pena, 2012a). Third, as academic group work is often encouraged in classrooms (Smith, 2006; Smith, Sheppard, Johnson, \& Johnson, 2005), the line between honest and dishonest collaboration is not clear (PérezPena, 2012a).

However, while many valuable insights have been gained into motivates individuals to cheat on their own (Anderman, Griesinger, \& Westerfield, 1998; Anderman \& Murdock, 2007), collective cheating, defined as students cheating together with in-group peers, is a form of cheating that has received relatively little attention in the research world. Consequently, the aim of this article is to explore collective cheating and identify who is likely to engage in it and under what circumstances. Specifically, we argue that loyalty to in-group members may, in certain contexts, predict a greater acceptance of collective but not individual cheating as well as collective cheating behavior. 


\section{A Motivational Approach to Cheating}

Educational literature has established strong ties between cheating and both extrinsic motivation as well as achievement goals (Murdock \& Anderman, 2006). Van Yperen, Hamstra, and van der Klauw (2011) showed the personal adoption of performanceapproach goals - achievement goals directed toward outperforming others - in learning to be a predictor of cheating. In a study carried out with middle school students, Anderman, Griesinger, and Westerfield (1998) also revealed that self-report cheating behavior was positively correlated with perceptions of classroom and institutional-level performance-goal orientation. Results of a longitudinal study have shown that students transferring from less performance-oriented middle school math classes to more performance-oriented high school math classes admit to increases in their cheating over the same period of time (Anderman \& Midgley, 2004). Experimental work (Murdock, Miller, \& Goetzinger, 2007; Murdock, Miller, \& Kohlhardt, 2004) also indicates a relationship between performance-oriented classrooms and the perceived justifiability of cheating. Furthermore, Anderman and Murdock (2007) and Anderman and Danner (2008) have highlighted relationships between performance goals and cheating.

Performance goals, along with extrinsic motivation, in other words desire for rewards and recognition (Anderman et al., 1998), have been grouped under the umbrella of motivating forces driven by external measures of achievement (Murdock \& Anderman, 2006) and interest in external measures of achievement has been associated with greater tendencies toward academic dishonesty (Anderman et al., 1998; Anderman \& Midgley, 2004; Murdock et al., 2004; Murdock, Hale, \& Weber, 2001; Toma \& Butera, 2009). This work is in line with studies that relate cheating to goals such as the desire to improve or maintain grades and classroom standing (Davis, Grover, Becker, \& McGregor, 1992; Davy, Kincaid, Smith, \& Trawick, 2007; Franklyn-Stokes \& Newstead, 1995; Haines, Diekhoff, Labeff, \& Clark, 1986; Newstead, FranklynStokes, \& Armstead, 1996; Rettinger, Jordan, \& Peschiera, 2004). This overarching theme of motivating forces driven by external measures of achievement brings us to the underlying importance of individual values or higher-order goals in the understanding of what motivates students to cheat. In the case of individual cheating, "self-enhancement" values, which are concerned with external measures of achievement: success, wealth, influence and public image (Schwartz, 2006) are relevant predictors of cheating attitudes and behavior (Pulfrey \& Butera, 2013).

\section{Values: A Way to Understand the Underlying Motivation to Cheat}

Within the educational psychology literature, the term value is commonly understood in terms of expectancy-value, notably the individual's beliefs about the degree to which they value an activity and how well they will do in it (Wigfield \& Eccles, 2000). However, the term value may also be viewed more broadly as a guiding principle in our lives. Values, with their role as guiding principles in our lives, underlying individual decision-making, attitudes, and behavior (Schwartz et al., 2012), are particularly relevant to understanding unethical behavior. Indeed, the role of individual values has been shown to relate to individual cheating (Pulfrey \& Butera, 2013) and that of institutional values has been explored in relation to cheating at university (McCabe, Treviño, \& Butterfield, 1999). Values constitute higher order goals (Schwartz, 2006) developed through socialization, that underlie motivational processes (Elliot, Chirkov, Kim, \& Sheldon, 2001; Schwartz, 2006). These, in turn influence attitudinal and behavioral outcomes (Chatzisarantis \& Biddle, 1998; Deci \& Ryan, 1987; Elliot, Shell, Henry, \& Maier, 2005; Harackiewicz, Barron, Tauer, \& Elliot, 2002; Linnenbrink \& Pintrich, 2002; Ryan \& Deci, 2000). More precisely, Schwartz (1992) defines individual-level values as central goals that relate to all aspects of behavior and constitute a source of motivation (Schwartz, 2006). In the abstract many things may seem important to us, but we do not have the time or energy to do them all and so we prioritize and make tradeoffs among values (Schwartz, 2006) as we choose how to act.

Schwartz (1992) proposes a circumplex model of 10 universal individual-level values, categorized in four value types. Proximity between values on the value "wheel" implies compatibility and distance indicates potential conflict, which means that diagonally opposed values will be antagonistic. The four value types include self-enhancement, self-transcendence, openness to change, and conservation. Self-enhancement values of achievement and power are concerned with personal success attained through the demonstration of normative competence, success attained competing with others and with control over resources and people, the concrete result of competition. Self-enhancement values are positioned diagonally opposite to self-transcendence values of universalism and benevolence, in which the wellbeing and interests of all others (universalism) or those close to us, our "in-groups" (benevolence) are prioritized.

Self-enhancing power and achievement values have been consistently related to less socially adaptive behavior. As Kasser, Cohn, Kanner, and Ryan, (2007) claim, the "winner takes all" mentality, the promotion of self-interest and the attachment of self-worth to a material success, leads to a tendency for people to form exchange-based relationships and to objectify others, judging them in terms of their potential usefulness. Further to this, Schwartz (2006) found that power and achievement values were negatively correlated with cooperation in a game context and found that the same values were related to a high concern for self and low concern for others. Other findings have linked materialistic value endorsement to greater Machiavellianism (distrust, egocentricity, and propensity for interpersonal manipulation; $\mathrm{McHo}-$ skey, 1999) and treating others in less caring ways (Kasser et al., 2007). Specific to cheating, Pulfrey and Butera (2013) have found robust associations between self-enhancement value adherence and individual student cheating. These results consolidate results of studies showing that students whose higher order goals for studying were to get a better job, earn more money and do better professionally than others, reported significantly more types of cheating behavior than students who studied for personal development reasons (Davy et al., 2007; Newstead et al., 1996).

\section{"Moral" Values: The Road to "Virtuous" Cheating?}

Not surprisingly, self-transcendence values, which sit opposite to self-enhancement values on the circumplex model, focusing as they do on the wellbeing of others (Schwartz et al., 2012), are generally considered to be highly moral values (Haidt, 2012; Schwartz, 2007; Vauclair, 2009), implying that they focus on 
actions that positively affect directly or indirectly the welfare of others (Kurtines \& Gewirtz, 1984). Results have also shown that they negatively predict the acceptance of cheating in learning contexts (Pulfrey \& Butera, 2016). On an institutional level, McCabe and Treviño (1993) provide evidence that the presence of honor codes promoting self-transcendent values reduces cheating by rendering it less normative.

However, self-transcendence values break down into two types of morality: universal fairness (universalism values) promoting wellbeing for all and "ingroup" loyalty and benevolence values promoting wellbeing for close ones. The latter are particularly relevant as classroom life is all about relationships. Friends usually sit together in class and spend recreation time together and group work is encouraged (Blatchford, Kutnick, Baines, \& Galton, 2003).

Benevolence values encapsulate the prioritization of loyalty toward one's in-group. Moral foundations theory (Graham, Haidt, \& Nosek, 2009) champions the inclusion of loyalty as a form of morality, asserting that in addition to the two classic moral dimensions of care for others (Gilligan, 1982) and fairness or justice (Kohlberg, 1976) there are up to four additional moral concerns for humans, one of which, notably, is loyalty to one's in-group. Values research provides strong support for the inclusion of loyalty to and concern for the in-group in the moral domain as in a study carried out with 100 Israeli adults in 1995, Schwartz determined what lay people considered to be moral values and found that $80 \%$ of his sample considered benevolence values-defined as the preservation and nurturing of the well being of those with whom one is in frequent contact, namely the in-group (Schwartz, 2007)—as the most moral values. Similar results emanate from an international research study carried out by Vauclair (2009) with 1,535 university students. This reflects Moll, de Oliveira-Souza, and Eslinger's (2003) argument that moral emotions, by definition, relate primordially to the welfare, cohesion, and order of the individual's in-group.

\section{"You Scratch My Back and I Scratch Yours:" Benefits of In-Group Loyalty}

Peer groups play a significant role in the educational process. The importance of in-group cooperation and loyalty is undeniably emphasized in research showing the benefits of group work (Baines, Blatchford, \& Chowne, 2007; Johnson \& Johnson, 1999), team activities (Harrison \& Narayan, 2003), group affiliations such as sororities and fraternities (Pike, 2003), and the development of solid, lasting friendships with other students (Wentzel, Barry, \& Caldwell, 2004) on student wellbeing and performance. In-group cooperation seems indeed to be an adaptive mechanism aiding academic survival for students today, just as evolutionary scientists have argued that it was necessary for human survival in huntergatherer societies (Boehm, 2012; Haidt, 2012; Wilson, 2012).

Why might this be? Apart from psychosocial benefits such as the satisfaction of the need for belonging, which increases student motivation and engagement (Osterman, 2000), group heuristics theory (Jin \& Yamagishi, 1997; Yamagishi, Jin, \& Miller, 1998; Yamagishi \& Kiyonari, 2000; Yamagishi, Mifune, Liu, \& Pauling, 2008) argues on that within an in-group people will tend to see a norm of generalized reciprocity. In other words, people generally act more cooperatively toward in-group members compared with the out-group and there is more likely to be an in-group trust-based norm of generalized reciprocity wherein favors rendered to group members will be returned from the group, even if not necessarily immediately from the same person.

\section{In-Group Favoritism: The Dark Side of In-Group Loyalty and Benevolence Values?}

While the collective adaptive benefits of in-group loyalty and cooperation are clear, is there a dark side to the adherence to benevolence values and, if so, how might this manifest in the classroom? According to the vast literature on in-group favoritism, this phenomenon is defined as the tendency to be more positive (Allport, 1954) and helpful (Fu, Tarnita, Christakis, Wang, Rand, \& Nowak, 2012) to members of one's own group than to those of other groups. This tendency is especially likely to occur as soon as any salient, value-laden basis for differentiation between an ingroup and an out-group can be discerned (Turner, 1975).

This preferential attitude and treatment of in-group fellows is particularly relevant to benevolence values. Schwartz (2007) teased out this question by means of a cross-cultural study, in which he first analyzed the degree to which groups of participants adhered to both benevolence and universalism values as opposed to predominantly benevolence values. He then created an index of moral inclusiveness, tapping into the degree to which people considered that being honest and forgiving, supporting justice, equality, and peace applied uniquely to those who are inside the in-group boundary as opposed to all other beings regardless of their social identities. Results showed that adherence to benevolence values, but not universalism values, indeed related to a discriminatory application of goodwill and good deeds to in-group over out-group members, a form of "limited good will" intended for in-group members alone. Following this logic, we argue that adherence to benevolence values in particular should be associated with greater prioritization of in-group well-being as opposed to the well-being of others generally and that this may create the basis for the justification of unethical pro-in-group behavior when certain contextual features are salient.

\section{The Intensifying Role of a Competitive Context}

Although a certain degree of in-group bias has been shown to occur even in the absence of a competitive social environment (Brewer, 1979), perceived potential threat to the in-group or any of its members from competition with external agents has been shown to play a key role in the explanation of active in-group bias. A host of studies has shown that it is in a context of competitive reward structures that attitudes and behaviors that maximize relative gain for the in-group are most enhanced (e.g., Brewer \& Silver, 1978; Ryen \& Kahn, 1975; Worchel, Andreoli, \& Folger, 1977). This can extend to behavior that violates moral codes (Cohen, Montoya, \& Insko, 2006; Sherif, Harvey, White, Hood, \& Sherif, 1961; Wildschut, Insko, \& Gaertner, 2002).

\section{In-Group Bias and Collective Cheating in the Academic Context}

Competition and inequality of resources are indisputably a central issue in society today (Cook \& Frank, 2010; Elliot, 2017) and 
this filters down to ever-increasing competition for places at top universities (Charles, 2014; Hartocollis, 2016; Ivywise, 2017; Pérez-Peña, 2014). Anderman, Maehr, and Midgley (1999), Elliot and Moller (2003), Nordmo and Samara (2009), Pope (2003), and Pulfrey, Buchs, and Butera (2011) argue also that competition remains a fact of life in many classrooms and university settings with the accompanying struggle for top grades (Deutsch, 1979; Ryan \& Weinstein, 2009). Even if teachers downplay competition within their classroom, students grow up with an awareness of it as a fact of life (Bahr, 2014) with parental pressure to succeed a socially recognized phenomenon (Carey, 2014) and this can create ambivalent attitudes toward friends in school. As Pope (2003, p. 39) documented in her case-based research in a Palo-Alto high school "students are often forced to choose between cheering on their friends or plotting against them." Research has documented the impact of competitive values and competition-salience in the environment on individual cheating (Anderman \& Danner, 2008; Pulfrey \& Butera, 2013; Whitley, 1998), but to our knowledge no research has directly addressed the question of collective cheating in a classroom context.

In laboratory studies, Weisel and Shalvi (2015) recently showed that individuals in dyads lie more about results of their individual die rolls when incentivized with team payoffs for certain teamlevel results. Hildreth, Gino, and Bazerman (2016) found that loyalty positively predicted individual cheating on behalf of the in-group when competition was high. In these studies, unethical acts are carried out by individuals on behalf either of status-driven real-life groups such as fraternities or else of experimentally created groups of individuals who did not previously know each other. Furthermore, both studies focus on an individual who is cheating in private in a situation of anonymity. As Weisel and Shalvi (2015) argue, this accurately captures the dynamics of some real-life situations in which individuals can act unethically without being identified.

But what about situations when peers cheat together? Sharing exam answers or copying off other students, passing on exam questions, copying a friend's report and having a friend do one's work for one are all real-life examples of what we term "collective cheating," in which individuals, in this case peers at school, actively collude with other members of the in-group with the aim of improving the results of in-group members relative to the out-group. We posit that such collective cheating is a potential way to rationalize the seeming paradox between being loyal to peers and succeeding. As such those who value peers and being loyal to them will be able to justify collective cheating but not individual cheating.

\section{Hypothesis and Overview}

More precisely, we hypothesize that, when competition is salient in one form or another, loyalty to peers will positively predict positive attitudes toward collective forms of cheating. Different forms of competition may be salient in students' psyches: societal level competition for jobs and wealth, grades-based competition for top colleges or cum laude GPAs in exams or classwork, and internalized values that promote a competitive approach to life, namely power values of wealth, public image, control over people, and resources (Schwartz et al., 2012). We examine our core hypothesis in the light of these different forms of competition.
In Study 1 we experimentally manipulate student awareness of a competitive society by evoking the portrayal of a relatively more competitive versus more cooperative societal context, in other words a free-market society in which competition for success is central, versus a society characterized by greater solidarity and support among people. We reanalyze data that showed that relative adherence to self-transcendence values in general (benevolence and universalism) negatively predicts cheating in general (both individual and collective acts of cheating; see Pulfrey \& Butera, 2016). In Study 1, we tease apart this result by splitting selftranscendence values and cheating attitudes into their component parts making it possible to test the specific association of relative adherence to benevolence (promoting in-group wellbeing) as opposed to universalism (promoting well-being of all others and nature) values with attitudes toward collective and individual cheating.

In Study 2 we evoke the GPA/grades-based type of competition as a contextual constant, using vignettes set in the context of an end of year university exam. Here we test whether relative adherence to benevolence values predicts moral disengagement toward collective cheating but not individual cheating.

As individual values are internalized through socialization (Schwartz, 2006), they are a valuable indicator of societal forces as learnt by children and young people, constituting a real lynchpin between social ideology and individual motivation. Study 3 focuses on this aspect of competition as a value system. Here we examined trait-level orientations toward in-group loyalty and competition testing the relation between simultaneous adherence to loyalty-related benevolence values and instrumental, competitionoriented, power-oriented values, and positive attitudes toward collective cheating. We hypothesized that the valuing of both loyalty and power (wealth, control over resources and people), would predict collective cheating.

Finally, Study 4 takes a behavioral approach, measuring the relation between working with someone you know and have points in common with versus working with a stranger on actual groupcheating behavior. We operationalize loyalty experimentally, comparing groups composed of students who know each other and perceive themselves to be similar to groups composed of strangers. In this study, as in Study 3, we assess the degree of chronic competitive orientation in groups by measuring individualadherence to power values. We hypothesize that groups composed of members who know each other and whose common interests are rendered salient, will be more likely to cheat than groups composed of strangers who perceive themselves as having nothing in common, and that this effect will be particularly strong when the groups are composed of members who value power.

\section{Study 1}

The aim of Study 1 was to test the impact of exposure to the portrayal of a macrosocietal context of competition in interaction with in-group loyalty benevolence-value adherence on attitudes toward collective cheating. We predicted an interaction effect between benevolence value adherence and societal context, with benevolence value adherence predicting acceptance of collective cheating in the condition in which a competitive societal context was portrayed but not in a control condition. We also tested the relation between universalism values and collective cheating and 
benevolence values and individual cheating to ascertain whether the predicted effect is specific to the benevolence-collective cheating relationship.

\section{Method}

Participants. One-hundred and 22 third-year students attending an international management school based in Switzerland, participated in this Study. The sample thus consisted of 46 male and 74 female students, with two missing values, with a mean age of $22.02(S D=1.73)$. The experiment was carried out in the economics class by a visiting researcher. As in all four studies, students were invited to participate in the study but also given the opportunity to get on with something else if they did not wish to take part. If any students did not take part, they were not included in the sample. The sample used in Study 1 is the same as that used in Study 2 of Pulfrey and Butera (2016). The interest of working with this sample is that in the original study the authors collapsed items of both benevolence and universalism values to measure the higher-order value of self-transcendence. In the present reanalysis we have separated universalism from benevolence (see Schwartz, 2007a). Moreover, their scale of acceptance of cheating included examples of both individual and collective behaviors, which can now be analyzed separately.

Procedure. Students filled in an individual values survey measuring their relative adherence to benevolence values (see below). Following this they were exposed to one of three experimental conditions. In two conditions, participants were instructed to read an extract from a lecture ostensibly given by a Nobel prize winner in Economic Sciences to business school students on the subject of the society they would shortly be entering (see Appen$\operatorname{dix} \mathrm{A}$ for text). Although the structure of both speeches was identical, in the competitive condition characteristics of society were drawn from peer-reviewed texts presenting a free-market ideology, policies, and structures (Beck, 1999; Clarke, 2004; Ericson, Barry, \& Doyle, 2000; Larner, 2000; Larner \& Craig, 2005; Rose, 1993). In the cooperative society condition, characteristics of society were drawn from the Giacalone and Thompson (2006) "human centered worldview" (HWV), characterized as an economy that goes beyond money, embracing physical as well as social wellbeing as necessary economic and business goals. A third control condition did not present any experimental manipulation (no text) in order to be sure not to render salient any other values which might have incidentally impacted the outcome variable. After the texts in the two experimental conditions, participants were asked to put down three words or phrases to describe the society they had just read about. The aim of this control question was to assure that participants had actually read the texts. Twentyone participants who put no words down at all and one participant who noted a totally inappropriate and irrelevant comment were excluded from the main analyses, leaving 100 participants who wrote down appropriate words, 31 in the competitive society condition, 31 in the cooperative society condition, and 38 in the control condition.

Following the experimental manipulation was a three-item scale of acceptance of cheating involving other in-group members (collective cheating) and a five-item scale of acceptance of individual acts of cheating (individual cheating; see below).
Values. The students' individual values were measured using an adapted version (Pulfrey \& Butera, 2013; Pulfrey \& Butera, 2016) of the Schwartz Portrait Values Questionnaire items (Schwartz et al., 2001) in which, for reasons of space, the questions addressed the respondent directly as opposed to asking the respondent to compare themselves to another person, and included 33 of the original 40 questions. The questionnaire included scales of items for the four higher-order value types: self-enhancement (six items: e.g., "It is important to me to be successful," $\alpha=.69$ ); self-transcendence divided into: universalism (five items: e.g., "It is important to me that every person in the world is treated equally;" $\alpha=.73$ ); and benevolence (three items: "It is important to me to help the people around me," “. . . to be loyal to my friends," ". . . to respond to the needs of others;" $\alpha=.67$ ); open to change (nine items: e.g., "It is important to me to think up new ideas and be creative;" $\alpha=.76$ ); conservation (10 items: e.g., "It is important to me to follow rules and do what one is told;" $\alpha=$ .67). The answer scale ranged from 1 (not at all important) to 7 (very important).

Schwartz (1992) individual values theory orders values in a circumplex model that captures the congruence or conflict between different values. If one values self-direction, one is not likely to value conformity and obedience and these values feature on opposite sides of the circumplex. The way that individuals trade off one value against another is the guiding force in attitude formation and behavior and individuals differ in their use of the response scales, some rating everything high and others sticking in the middle; thus, it is necessary to correct individual differences in the response scale in order to capture value priorities (Schwartz, 2006). Consequently, we calculated each individual's overall average score for all values and then subtracted this mean value score from their score on benevolence values (relative benevolence $=$ raw score benevolence-individual mean score for all values), thus creating a score of benevolence relative to other values (as recommended by Schwartz, 2006). The resulting individual score was used in the regression models. Hedonism values were included with the open to change value type.

Acceptance of cheating scales. In the questionnaire used by Pulfrey and Butera (2016), a range of items associated with academic dishonesty was created. In the present reanalysis, initial exploratory factor analysis using Direct Oblimin rotation was used to discard items that had multiple loadings or no high loadings on any one factor. This left two factors with eigenvalues over 1 . The first factor included five acceptance of individual cheating items $(\alpha=.91)$ and explained $52 \%$ of the variance. The second factor included three acceptance of collective cheating items $(\alpha=.77)$ and explained a further $20.76 \%$ of the variance. The factor analysis breakdown is presented in Table 1 and descriptive statistics in Table 2 .

A confirmatory factor analysis of the two cheating scales revealed a good model fit, $\chi^{2}=29.90, n s, \chi^{2} / d f=1.57$, RMSEA $=$ $0.07, \mathrm{CFI}=0.98, \mathrm{SRMR}=0.05$, and one of the entire measurement model, namely the two cheating scales and the two values scales, universalism and benevolence, equally revealed good model fit, $\chi^{2}=137.75, p>.001, \chi^{2} / d f=1.41$, RMSEA $=0.06$, $\mathrm{CFI}=0.95, \mathrm{SRMR}=0.07)$. We did not have problems with abnormal distributions. 
Table 1

Study $1(N=122)$ : Exploratory Factor Analysis-Acceptance of Individual and

Collective Cheating

\begin{tabular}{lcc}
\hline & \multicolumn{2}{c}{ Factor loadings } \\
\cline { 2 - 3 } Item: In my courses, I think it's ok sometimes to: & $\begin{array}{c}\text { Factor 1 } \\
\text { (Individual) }\end{array}$ (Coctlective) \\
\hline Put in a reference to an article without looking it up & .87 & .19 \\
Get homework answers off the web without referencing them & .88 & .30 \\
Copy some good material off the web without referencing & .88 & .30 \\
Have someone else write a paper for me & .85 & .23 \\
Resubmit a project that I've done before for another class & .76 & .38 \\
Get test-related information off friends who took the test earlier in the day or week & .30 & .86 \\
Share individual homework answers & .38 & .78 \\
Get help on my assignments from family members or friends outside school & .14 & .81 \\
\hline
\end{tabular}

\section{Results}

To test the hypothesis that the relationship between benevolence and collective cheating will be especially positive in a competitive environment, we ran dummy-coded regression analyses with the control condition as the reference condition, coded 0 . The model therefore included two contrasts-the competitive contrast (control Condition 0, competitive Condition 1, cooperative Condition 0), and the cooperative contrast (control condition 0 , competitive condition 0 , cooperative Condition 1) -relative benevolence value adherence and interactions between the contrasts and benevolence values. Preliminary regression analyses run with all the terms of the model revealed the presence of one outlier (studentized deleted residual $=-2.73$ ) and so this case was removed from the main analyses leaving a total of 99 participants. Results revealed no main effects of condition or of relative benevolence value adherence on acceptance of collective cheating, but the predicted interaction effect between adherence to benevolence values and contrast one, the competitive contrast, was significant, $B=1.52, F(1$, $94)=7.51, p=.008, \eta^{2}=.05,95 \%$ CI $[0.53,2.50]$. No other effects in the model were significant.

Examination of the interaction effect revealed that adherence to benevolence values positively predicted positive attitudes toward acts of collective cheating in the competitive society condition, $B=1.12, F(1,94)=9.18, p=.003, \eta^{2}=0.24,95 \%$ CI $[0.41$, 1.82]. but not in the control condition, $B=-0.40, F(1$, $94)=-0.87, n s, 95 \%$ CI $[-1.13,0.33]$ or the cooperative condition, $B=0.46, F(1,94)=0.86, n s, 95 \%$ CI $[-0.42,1.35]$.

To test whether the relationship between benevolence and collective cheating was unique, we ran a second regression model with relative universalism instead of benevolence values, which revealed no significant effects, (interaction effect between adherence to universalism values and contrast one, the competitive contrast, $B=0.90), F(1,94)=3.13$, ns. We also ran a third regression model with benevolence value adherence as independent variable and individual cheating as dependent variable. This revealed no significant effects (interaction effect between adherence to benevolence values and contrast one, the competitive contrast, $B=0.57), F(1,94)=0.53, n s$.

\section{Discussion}

Results revealed that an increase in relative adherence to benevolence values positively predicted attitudes toward collective cheating in a context in which competitive societal practices and values were promoted but not in a control condition. This effect was not observed for the comparison between the control condition and a context in which cooperative societal practices and values were promoted. Nor was it observed for the relationship between benevolence value adherence and attitudes toward individual cheating. The relationship between universalism value adherence and attitudes toward collective cheating was also nonsignificant in all conditions. These results indicate that more positive attitudes toward acts of collective cheating indeed seem to be above all related to benevolence values, in a context in which a competitive societal environment is salient.

Study 1 used the evocation of a relatively distal and macro societal environment to render competition salient. This portrayal of the external world might prime future career-related aspirations in which the collective, in-group can play a significant part in the development of a successful career (Tsui \& Fahr, 1997). The fact that the impact of the cooperative society representation on attitudes toward collective cheating is situated between that of the control condition and that of the competitive society with a simple slope beta coefficient that is positive, although not significantly so

Table 2

Study $1(N=122)$ : Descriptive Statistics and Zero-Order Correlations Among Variables

\begin{tabular}{lrrrrr}
\hline \multicolumn{1}{c}{ Variables } & $M$ & \multicolumn{1}{c}{$S D$} & Range & (2) & $(3)$ \\
\hline Benevolence values (relative) (1) & .35 & .59 & $-1.39-1.82$ & .06 & -.03 \\
Acceptance of collective cheating (2) & 4.34 & 1.39 & $1.33-7.00$ & - & $.35^{\text {******* }}$ \\
Acceptance of individual cheating (3) & 2.62 & 1.30 & $1.00-7.00$ & - & - \\
\hline
\end{tabular}

**** $p<.001$. 
and not significantly different from the control condition, might support this argument.

Within the classroom context although practices may not focus on competition, the bottom line of the GPA and the consequences it holds, at high school level for accessing increasingly selective top-level universities and at college level for recruitment for toplevel jobs, also imposes competitive pressure on students (Pulfrey, Darnon, \& Butera, 2013). This is particularly the case seeing that however much groupwork may be organized in the classroom, the majority of school and college evaluation is individual (Tyler et al., 2008). Competition between students has consistently been associated with explanations of individual cheating (Gallant \& Drinan, 2006; McCabe \& Trevino, 2002; Murdock \& Anderman, 2006). Consequently, in the following study, our first aim is to focus on the question as to whether, within a proximal environment of individualistic competition, namely an end-of-year exam, adherence to benevolence group-oriented values still positively predicts positive attitudes toward collective forms of cheating.

Because in Study 1 attitudes toward cheating were measured, which did not allow direct comparison between individual and collective cheating, our second aim in Study 2 was to provide an alternative way of measuring attitudes toward cheating. We accomplished this by creating a set of vignettes describing individual versus collective forms of cheating and measuring the degree to which participants engaged in a form of moral disengagement toward them. The vignette approach has already been used in research on individual cheating (Rettinger et al., 2004) and has the advantage of capturing attitudes more indirectly as participants judge the behavior of others. The behaviors portrayed in the vignettes that we ask participants to assess, all directly violate the basic rules of an individually based examination system in one way or another. Thus, any degree of acceptance of them will require moral justification, whereby ways are sought to reinterpret specific behaviors as morally acceptable (Bandura, 2002), by means of cognitive mechanisms to allay self-regulatory censure. Moral disengagement theory (Bandura, 2002) offers a range of cognitive techniques by which potential guilt may be assuaged (Shu, Gino, \& Bazerman, 2011). Moral principles that are, in fact, violated are thus perceived to be respected (Tsang, 2002).

Just as individual cheating has been shown to take a range of forms (Pope, 2003), collective cheating might manifest itself in a number of different ways and our third aim was to address this little-explored question. In-group cooperation within the context of an individual exam is likely to manifest itself in the form of self-interested helping or reciprocal altruism (Trivers, 1971), in which the individual is motivated to work in collusion with other in-group members for mutual benefit. We investigate three forms that this might take: in-group-sharing of resources, individual altruism in which one individual helps the rest of the group, and in-group versus out-group stealing in which in-group members copy off other students.

In-group resource-sharing constitutes real-time, in-group based investment with immediate pay-off, manifested by in-group members sharing their answers. Individual altruism or reciprocal altruism is argued to constitute a staggered form of cooperation consisting of time-one, in-group investment from an individual that is accompanied by the potential expectation of time-two reciprocation of some sort from the other group members (Axelrod \& Hamilton, 1981). This latter form of cooperation in the context of an exam would be manifested by one group-member sharing answers with the others. The third form of collective cheating, namely in-group versus out-group stealing is particularly relevant to the findings that relative adherence to benevolence values and hence to a lesser extent their neighboring value universalism, predicts bounded morality applicable to the in-group context (Schwartz, 2007a). In Study 2, therefore, we aim to test the degree to which relative benevolence-value adherence predicts moral disengagement toward these three types of collective cheating in comparison with individual cheating.

\section{Study 2}

Integrating the above questions, in Study 2 we test the hypothesis that, within the individually competitive context of an end of year selection exam, adherence to benevolence values will predict moral disengagement for collective cheating (in-group resource sharing, altruistic sharing, in-group vs. out-group copying) to a greater extent than for individual cheating (individual copying for individual gain).

\section{Method}

Participants. Eighty-two second- and third-year students in the social sciences department of a French-speaking Swiss University, with a mean age of $21.89(S D=2.52)$, participated in this study. This sample consisted of 12 male and 69 female students, with one missing value. The experiment was carried out in the context of the students' social psychology classes and included all the students present the day of the administration.

Procedure. Students were asked if they would be willing to complete two separate surveys. The aim of the first survey was to find out their opinions about their lives and studies and the aim of the second was to find out their opinions about the university system and its norms. They were also told that we were particularly interested in the views of second and third year students as they had by now acquired a certain experience of university life. All students in the class agreed to participate.

Participants then completed the two surveys, which were both anonymous. Discrete coding, disguised as a patent number at the bottom of the page, made it possible to link each individual's two surveys. The first survey consisted of the same values questionnaire as used in Study 1. The second survey featured one of four possible vignettes, portraying individual cheating $(N=22)$, groupsharing $(N=20)$, one student helping in-group members (altruistic cheating; $N=20$ ) and in-group members copying off other (outgroup) students (collective copying; $N=20$ ). All the texts were preceded by the following introduction: "The text below is a personal account of Alex, a student at this university. Please read the text." The name Alex was chosen as it is a common unisex name. The texts (English translation) are presented in full in Appendix B and an example of the French version is presented in Appendix C.

The vignettes were followed by a scale of moral disengagement and opinions of the actions portrayed in the vignette, adapted from Shu, Gino, and Bazerman (2011).

\section{Measures.}

Values. The same measure of values was used as in Study 1: self-enhancement ( $\alpha=.72$ ); self-transcendence divided into uni- 
versalism $(\alpha=.72)$ and benevolence $(\alpha=.60)$; open to change $(\alpha=.70)$; conservation $(\alpha=.73)$. The relative benevolence score was calculated as in Study 1.

Moral disengagement. The six items of the Shu et al. (2011) scale were translated into French (e.g., "Sometimes getting ahead of the curve is more important than adhering to rules," "End results are more important than the means by which one pursues them"), and adapted to be applicable to the behavior of the student/s described in the four vignettes: "Concerning the actions of Alex (and of his/her friends)." The word "cheating" was removed from the two questions that contained it to allow for unbiased participant interpretation of the action in the vignettes. Six additional items were added to the scale, for example "Sometimes it's acceptable to do this," "It's more or less normal," to ensure that it captured the participant's express approval and rationalization of the acts being described. An initial exploratory factor analysis with all 12 items revealed that one of the Shu et al. (2011) scale items, namely "If others engage in cheating behavior, then the behavior is morally permissible" loaded negatively on the first main factor. A confirmatory factor analysis carried out with just the six Shu et al. (2011) items confirmed that this item did not load significantly on the scale factor. Consequently, a second exploratory factor analysis was run with the other 11 items (see Table 3). Results revealed a first main factor that includes the other five Shu et al. (2011) items as well as three of the additional items, explaining $42.56 \%$ of the variance. To check on model fit for this factor, a confirmatory factor analysis was run using structural equation modeling (Stata). The initial model showed inadequate indices of fit. $\chi^{2}=54.21 \mathrm{~ns}$ $\chi^{2} / 2=2.71$, RMSEA $=0.146, \mathrm{CFI}=0.87, \mathrm{SRMR}=0.06,(\alpha=$ .85). Removing one item, "It's no big deal," (modification index: 26.86), provided a seven-item scale with good fit, $\chi^{2}=18.22, n s$ $\chi^{2} / 2=1.30$, RMSEA $=0.06, \mathrm{CFI}=0.98, \mathrm{SRMR}=0.04,(\alpha=$ .84.). Once again we ran a full SEM measurement model containing benevolence value and moral disengagement items. The model showed excellent fit, $\chi^{2}=37.19 n s \chi^{2} / 2=1.09$, RMSEA $=0.03$, $\mathrm{CFI}=0.99$, SRMR $=0.06$. We did not have problems with outliers or abnormal distributions. Descriptive statistics appear in Table 4.

\section{Results}

To test the hypothesis that within the context of a competitive exam, benevolence value adherence will predict greater moral disengagement toward collective than individual cheating, we ran robust regression analyses, which automatically control for any deviations from normality in the data. In a first set of analyses, we created three orthogonal contrasts. The first contrast pitted the individual cheating condition (coded 3 ) against the three collective cheating conditions (coded -1 ). In the second contrast the individual condition was coded 0 , the group cheating off other students was coded 2 and the two sharing conditions were coded -1 . In the third contrast the individual condition and the group cheating off other students were coded 0 , the individual sharing with the group was coded -1 and the group sharing was coded 1 . The model thus contained eight terms: relative benevolence value adherence, the three contrasts, interactions between benevolence value adherence and the three contrasts, and gender as a control variable, as a $\chi^{2}$ test revealed a significantly higher number of female than male participants, $\chi^{2}(82)=97.49, p<.001$ (see Figure 1 ).

Results revealed a main effect of the first contrast (individual cheating vs. collective cheating) with participants generally morally disengaging toward the individual cheating condition more than the collective conditions, $B=0.32, F(1,76)=5.15, p=.03$, $\eta^{2}=.08,95 \%$ CI $[0.04,0.60]$. However, there was also an interaction between the first contrast and benevolence value adherence, $B=-0.38, F(1,76)=6.61, p=.01, \eta^{2}=.10,95 \% \mathrm{CI}$ $[-0.68,-0.09]$ showing that, consistent with our hypothesis, as adherence to benevolence values increased so did moral disengagement toward the three acts of collective relative to individual cheating. Examination of simple effects revealed first that while benevolence value adherence negatively but not significantly predicted moral disengagement in the individual cheating condition, $B=-0.86, F(1,76)=0.29, n s, \eta^{2}=.12,95 \%$ CI [-1.99, 0.27], it positively predicted it in the collective conditions, $B=0.57, F(1$, 76) $=4.67, p<.05, \eta^{2}=.08,95 \%$ CI $[0.04,1.10]$. There was a main effect of gender, $B=-1.10, F(1,76)=11.70, p=.001$, $\eta^{2}=.11,95 \%$ CI $[-1.76,0.35]$ with men morally disengaging more than women. No other effects were significant.

Supplementary analyses. In order to understand precisely which of the collective conditions were driving these results and to what extent condemnation of self-serving individual cheating was differentiated from the other three in-group-serving conditions, we carried out a second set of analyses using dummy coding to compare each collective condition with the individual cheating one. Gender was once again included in the model as was benev-

Table 3

Study $2(N=82)$ : Exploratory Factor Analysis for Extended Moral Disengagement Scale

\begin{tabular}{lcr}
\hline \multicolumn{1}{c}{ Item: Concerning the actions of Alex (and of his/her friends): } & Factor 1 & Factor 2 \\
\hline Sometimes getting ahead of the curve is more important than adhering to rules. & .68 & .40 \\
End results are more important than the means by which one pursues them. & .55 & .14 \\
Rules should be flexible enough to be adapted to different situations. & .54 & -.08 \\
It's appropriate to seek short cuts as long as it's not at someone else's expense. & .77 & .17 \\
Sometimes it's acceptable to do this. & .80 & .16 \\
It's more or less normal. & .63 & .47 \\
It doesn't hurt anyone. & .77 & .16 \\
Items not included in final scale. & .46 & .63 \\
When it comes to it, I can understand Alex/them. & -.07 & .76 \\
It's not surprising. & .06 & .76 \\
That's how it is. & & .76 \\
It's no big deal (ulterior CFA revealed covariance with "It doesn't hurt anyone;" & -.09 \\
MI = 26.86). & & \\
\hline
\end{tabular}


Table 4

Study $2(N=82)$ : Descriptive Statistics and Zero-Order Correlations Among Variables

\begin{tabular}{lrrrr}
\hline \multicolumn{1}{c}{ Variables } & $M$ & \multicolumn{1}{c}{$S D$} & \multicolumn{1}{c}{ Range } & $(2)$ \\
\hline Benevolence values (relative) (1) & .74 & .49 & $-.52-1.98$ & .02 \\
Moral disengagement (2) & 3.75 & 1.12 & $1.00-6.43$ & - \\
\hline
\end{tabular}

olence value adherence and the interactions between the three contrasts and benevolence values, giving eight terms in all in the regression model. Results indicated a main negative effect of the contrast comparing Condition 2 (group collectively copying off other people) with Condition 1 (individual copying off other people), $B=-1.67, F(1,76)=7.02, p=.01,95 \% \mathrm{CI}$ $[-2.91,-0.41]$.

More interestingly, there was a also positive interaction effect between the contrast opposing Condition 2 (group collectively copying off other people) to Condition 1 (individual copying off other people) and adherence to benevolence values, $B=2.00, F(1$, $78)=8.18, p=.006,95 \%$ CI $[0.59,3.32]$, showing that benevolence value adherence tended to predict moral disengagement to a greater extent for group collectively copying off other people compared with individual copying off other people.

As in the first analyses, there was a main effect of gender, $B=-1.10, F(1,78)=8.94, p=.004, \eta^{2}=.11,95 \% \mathrm{CI}$ $[-1.76,-0.35]$, with men morally disengaging more than women. Results are presented in Figure 2.

Robustness check for interaction effect. Because Study 2 has a small sample size, we performed a robustness check to verify that the interaction effect was not simply due to chance. To do this we ran two Monte-Carlo simulations, which are very useful for establishing the power of a test (Muthen \& Muthen, 2002). The first of these used normally distributed random variables for the continuous predictors, and the continuous dependent variable; we used the actual variables' means and standard deviations as a basis for the random generation process. We generated binomial variables for three dummy-coded contrasts used to compare the three collective cheating conditions with the individual cheating condition, as well as gender, using the percentages from the real variables as a basis for the random generation process. In this way, we were able to determine what the likelihood was to detect a significant interaction, where one does not exist in the population, knowing that with increasing $k$ predictors and a small $n$ the probability of detecting an interaction increases by chance alone (see Jacquart \& Antonakis, 2015). The second simulation was based on the observed variance-covariance matrix of the data analyzed in Study 2. We drew sample data (at $n=82$ ) from this population matrix, assuming a multivariate normal distribution, using Stata's "drawnorm" command (to simulate different sampling contexts). We then ran each simulation 5,000 times, generated the $t$-statistics for each of the terms in the model and used this value to calculate the probability of detecting a significant interaction effect (see Antonakis \& House, 2014, Study 4).

Results from the first Monte Carlo revealed that the interaction of our relative adherence to benevolence values and each of the three collective cheating contrasts in the random model had no more than a $6 \%$ chance of producing a significant effect on the dependent variable. However, from the second Monte Carlo sim- ulation, in the actual model, the interaction of the dummy-coded contrast, comparing Condition 2, (group copying off others) to Condition 1 (individual cheating), and benevolence adherence, showed an $83 \%$ chance of producing a significant result. Testing the model with larger sample size would obviously increase the probability of detecting a significant result across the three interactions. Overall, these results indicate that the significant effect we observe seems to be stable and not due to chance despite the smallish sample size.

\section{Discussion}

Results of Study 2 revealed that in a context of individually focused competition that students regularly face in their end of year of exams, adherence to benevolence values positively predicted moral disengagement in the three collective cheating scenarios to a greater extent than in the vignette depicting individual cheating. Further analyses specified that this difference between collective and individual cheating was significant for group collectively copying off other people, and marginal for both group sharing answers and individual providing answers to in-group.

These results complement those of Study 1, showing that even in a context of individual, immediate competition, adherence to benevolence values seems indeed to go with the condoning of collectively orchestrated pro-in-group cheating, particularly cheating that actively exploits out-group resources in order to benefit the in-group. At the same time adherence to these same values does not predict moral justification of acts of individual cheating, once again supporting the clear distinction between these two types of academic dishonesty. We also see a main effect of gender with men morally disengaging toward cheating more than women, an effect which replicates a number of other gender-cheating related findings (Athanasou \& Olasehinde, 2002).

\section{Study 3}

While in the first two studies we have worked with benevolence values as a whole, Schwartz et al. (2012) have recently

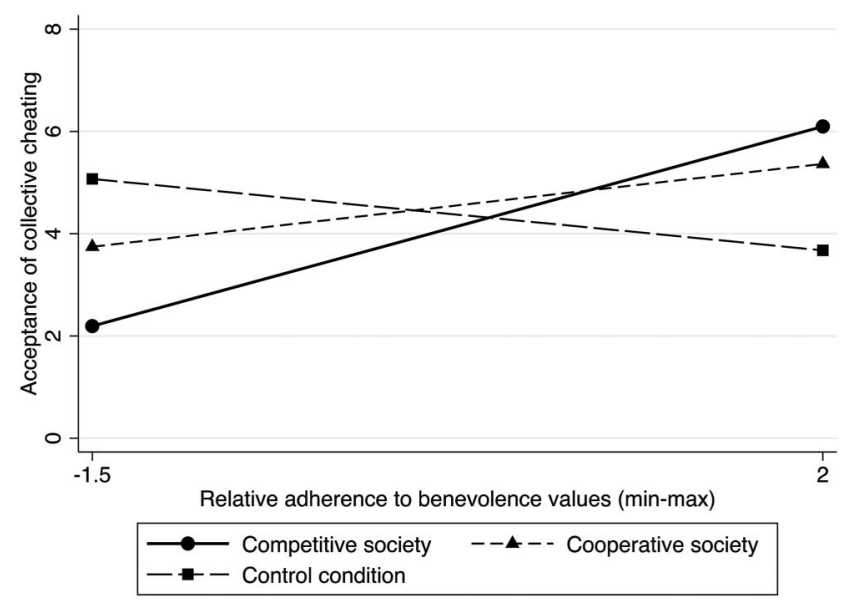

Figure 1. Study 1: Interaction between relative adherence to benevolence values and portrayal of competitive versus cooperative society by Nobel Economics Prize winner. 


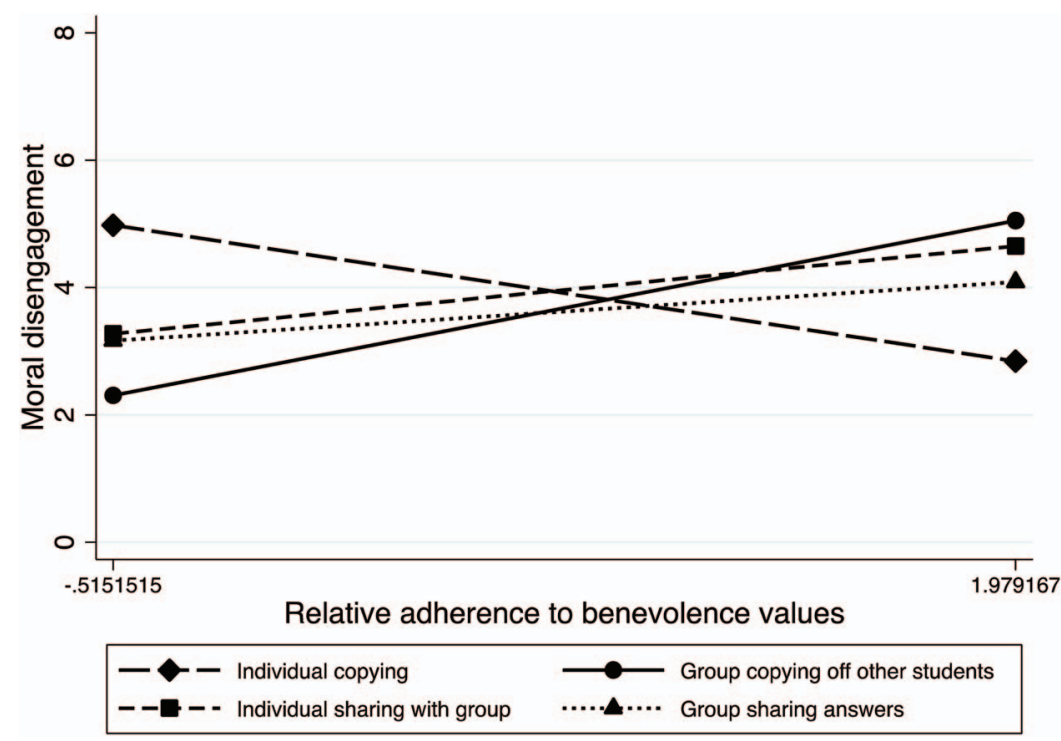

Figure 2. Study 2: Interaction between relative adherence to benevolence values and vignette portrayal of four different types of exam cheating.

identified two subtypes of benevolence value: (a) benevolencecaring (helpful, working for others' welfare, honest, forgiving), a value type more related to family; and (b) benevolencedependability (being dependable, loyal to friends), a value-type more related to friends. What type of benevolence is at the heart of the acceptance of collective cheating? We would argue that, in the context of the academic arena on which we have thus far focused, benevolence dependability, with its strong focus on in-group loyalty will be more relevant in predicting more positive attitudes to collective cheating carried out with friends than caring benevolence, with its more generically moral characteristics of helpfulness, honesty and charity. We address this question in Study 3.

A second question addressed in Study 3 is that of the role of competition as an internalized pressure that is instrumental for getting what one desires. Thus far competition has featured as a situational variable, a societal level variable manipulated in Study 1 and an institutional-level variable, held constant in Study 2. However, both types of competition are likely to put pressure on students precisely because they pose a potential threat to obtaining valuable goods and resources. Values are internalized through socialization from key social agents such as parents, peers, media and education (Schwartz, 2006). As such, students are likely to have a generic adherence to certain values via their upbringing. We argue that students who adhere to power values, with their focus on "social status and prestige, control or dominance over people and resources"(Schwartz et al., 2012, p. 664), are likely to have a chronically competitive view of life as access to these things inevitably implies a competitive drive to outperform others. Furthermore, research (Pulfrey \& Butera, 2013) indicates that pure adherence to power and achievement values relative to other values is a direct predictor of individual cheating. So how might the individual who both craves power but is at the same time strongly loyal to their in-group behave?
Technically speaking, although power and benevolence values are theoretically positioned at opposite poles of the values circumplex, recent research has highlighted the fact that benevolence values are generally centrally situated within the circle, implying that they have a potentially universal quality (Schwartz \& Butenko, 2014). Indeed, Schwartz (2007b), in the context of cultural differences in values, pointed out that the U.S. population is positioned relatively high on power and achievement values and correspondingly low on universalism values, but not as low on benevolence values. Consequently, the dual adherence to pro-in-group benevolence values and power values, which may be upheld for the individual him or herself and also for the group to which he or she belongs, is not necessarily incompatible.

Thus, the dual aim of Study 3 is to add precision to the previous two studies by pinpointing the type of benevolence associated with collective cheating and to extend them by testing the impact of trait competitiveness as portrayed by individual adherence to power values. We hypothesize that the simultaneous adherence to both benevolence-dependability (in-group loyalty) and power values should be likely to predict collective cheating. However, this should be less the case for adherence to benevolence-caring values.

\section{Method}

Participants. Three-hundred and 21 students in the social sciences department of a French-speaking Swiss university, with a mean age of 20.72 ( $S D=4.13)$, participated in this study. This sample consisted of 67 male and 254 female students.

Procedure. The experiment was carried out in the context of a first-year social psychology class. Students were invited to fill in a paper and pencil survey. Participation was voluntary and all students present that day accepted to participate. The values and cheating questions formed part of a larger survey, destined to 
validate a French version of Schwartz et al.'s (2012) refined values questionnaire (Pulfrey, Schwartz, Crouzevialle, \& Butera, 2017).

\section{Measures.}

Values. The French version of the new refined values survey PVQ-R (Schwartz et al., 2012, validated by Pulfrey et al., 2017) was used, including benevolence dependability $(\alpha=.59)$, benevolence caring $(\alpha=.76)$, and power $(\alpha=.82)$. As we were testing an interaction between two individually held values, we did not use relative scores.

Acceptance of collective cheating. The same three-item scale of acceptance of acts of collective cheating behavior was used as in Study $1(\alpha=.66)$.

Acceptance of individual cheating. The same five-item scale of acceptance of acts of individual cheating behavior was used as in Study $1(\alpha=.88)$. Descriptive statistics are presented in Table 5.

As the reliability for benevolence dependability was low and we were interested in the potential structural validity of two value types that normally sit on opposite sides of the Schwartz circumplex model (Schwartz, 1992), we examined the structural relations between our three key variables of interest, entering the items of benevolence-dependence and power values and acceptance of collective cheating in a multidimensional scaling analysis using SPSS. Results revealed excellent fit, S-Stress, .002, D.A.F., 1.00, Tucker's Coefficient of Congruence, 1.00, with the items of the respective variables closely clustered and the three variables occupying distinct spaces in the diagram. We did not have problems with outliers.

\section{Results}

In order to test the assumption that simultaneous adherence to both benevolence-dependability and power values would predict acceptance of collective cheating, we used raw score valueadherence measures for the power and benevolence dimensions. The basic regression model included 22 terms: adherence to benevolence-dependability and benevolence-caring values, adherence to power values, the interaction between power and benevolence-dependability, the interaction between power and benevolence-caring, the remaining 16 values and gender included as a control variable. No variables needed to be omitted because of collinearity. As the dependent variable, acceptance of collective cheating, showed a left skew $(M=5.30, S D=1.08)$, we used a Stata general linear model with a family (Poisson) option and robust standard error estimates for the regression analysis, (Statalist, 2010; Stata User's Guide, 2015).
Results of the model revealed the predicted interaction effect of benevolence dependability and power, $B=0.05, S E=.02, Z=$ $2.35, p=.02,95 \% \mathrm{CI}[0.01,0.08]$, implying that as adherence to benevolence dependability and to power both increase, so does acceptance of acts of collective cheating. Examination of simple slope effects showed that at high levels of power value adherence $(+1 S D)$, adherence to benevolence-dependability values positively predicted acceptance of collective cheating, $B=0.06, S E=$ $.03, Z=2.46, p=.01,95 \%$ CI [0.01, 0.12], but at low levels of power value adherence $(-1 S D)$, the relationship between benevolence-dependability and cheating acceptance was not significant, $B=-0.03, S E=.03, Z=-0.78, n s$.

The interaction between benevolence caring and power was not significant, $B=0.00, S E=.02, Z=0.01$, $n$ s Additional significant effects of values included adherence to conformity to rules, which negatively predicted collective cheating acceptance, $B=-0.04, S E=.01, Z=-2.88, p=.004,95 \%$ CI $[-0.07$, $0.02]$, as did self-direction of thought, $B=-0.05, S E=.02$, $Z=-2.62, p=.01,95 \% \mathrm{CI}[0.09,0.01]$. Hedonism had a positive effect, $B=0.05, S E=.02, Z=2.28, p=.02,95 \%$ CI [0.01, 0.09]. No other effects were significant.

In order to find out if this combination of benevolencedependability and power uniquely predicted acceptance of collective but not individual cheating, we also tested the model with individual cheating as dependent variable. Results of the same model using a link (log) function-as acceptance of individual cheating showed a left skew, $(M=2.54, S D=1.09)$ —showed no significant effect of the combination of these two variables on acceptance of individual cheating, $B=0.04, S E=.03, Z=1.41$, $n s, 95 \%$ CI $[-0.02,0.10]$. However, there was a significant main effect of adherence to power values, $B=0.08, S E=.03, Z=2.25$, $p=.02,95 \%$ CI $[-0.01,0.14]$ and an effect of gender on individual cheating, with male participants showing higher levels of acceptance of individual cheating, $B=-0.23, S E=.07$, $Z=-3.58, p<.001$, CI $[-0.01,0.14]$.

\section{Discussion}

These results show that combined adherence to power values and benevolence-dependability values - with their focus on friendship, loyalty, and being a reliable group member (Schwartz et al., 2012) - was associated with acceptance of acts of collective cheating, but not with acceptance of acts of individual cheating. Benevolence-caring did not interact in the same way with power values to predict collective cheating acceptance. It would thus seem that, from an intrapersonal point of view too, in-group

Table 5

Study $3(N=321)$ : Descriptive Statistics and Zero-Order Correlations Among Variables

\begin{tabular}{lcccccccc}
\hline \multicolumn{1}{c}{ Variables } & $M$ & $S D$ & Range & (2) & (3) & (4) & (5) & (6) \\
\hline Benevolence dependability values (1) & 5.31 & .70 & $2.33-6.00$ & $.57^{* * *}$ & -.01 & -.03 & .08 & -.07 \\
Benevolence caring values (2) & 5.40 & .65 & $3.00-6.33$ & - & $-.15^{* *}$ & .03 & .04 & -.10 \\
Power dominance values (3) & 2.90 & 1.13 & $1.00-6.00$ & - & - & $.47^{* * *}$ & .06 & $.12^{*}$ \\
Power resources values (4) & 2.64 & 1.18 & $1.00-5.67$ & - & - & - & .02 & .06 \\
Acceptance of collective cheating (5) & 5.29 & 1.08 & $1.00-7.00$ & - & - & - & - & $.36^{* * *}$ \\
Acceptance of individual cheating (6) & 2.65 & 1.13 & $1.00-7.00$ & - & - & - & - & - \\
\hline
\end{tabular}

${ }^{*} p<.05 . \quad{ }^{* * *} p<.01 . \quad{ }^{* * *} p \leq .001$. 
loyalty combined specifically with the desire to gain power is a predictor of more accepting attitudes toward collective cheating.

We have seen that in-group loyalty values of benevolence predict positive attitudes toward collective, not individual cheating, within competitive contexts and that, in combination with power value adherence reveal a general trait-level acceptance of collective cheating. There is considerable literature that demonstrates reliable links between attitudes toward individual cheating and cheating behavior (Jordan, 2001; Whitley, 1998), and in this respect the results of the above three studies provide an important contribution to the literature on cheating.

\section{Study 4}

In our fourth and final study, we had three key objectives: to operationalize in-group loyalty as opposed to measuring it via the adherence to benevolence values, to relate it to cheating behavior.

Operationalizing in-group loyalty is a valuable addition to this suite of studies as it allows us to establish causality and overcome the limitation of a self-report measure. To do this we combined two ways of creating in-group loyalty: existing member familiarity and the active generation of perceptions of similarity (a "birds of a feather flock together" effect). In-group loyalty and benevolence values revolve around enhancing the wellbeing of in-group members, including the self (Schwartz et al., 2012). Harmonious group functioning and the individual need for acceptance or relatedness are underlying objectives (Schwartz, 2006). Both familiarity with other group members and perceptions of other group members as similar to the self should trigger greater feelings of loyalty toward others in the group than a context in which group members are strangers and perceive themselves as different from the other group members. We care more about those who are close and like us than those who are strangers and different from us. Thus, we operationalized in-group loyalty by means of groups in which group members knew each other and perceived that they had things in common. This is particularly relevant to the educational context as when group work is set up, often students are allowed a free choice of group members, which usually produces a large number of friendship groups or at least groups of individuals who have something in common with each other.

Our second key objective was to test the impact of in-group loyalty on actual cheating behavior. It is one thing to self-report attitudes to cheating in an anonymous, individual survey, but quite another to actually engage in cheating in the presence of someone else. Consequently, measuring collective cheating in this way constitutes a significant addition to the contribution provided by this article.

In Studies 1 and 2, we worked with in-group loyalty via measured adherence to benevolence values in contexts that were competitive. In Study 3 we measured adherence to both benevolence and power values. An additional objective in Study 4 was therefore to confirm and extend the results of Study 3 by again measuring adherence to individual values of power.

Summing up, we hypothesized a positive interaction between familiarity and participant adherence to power values, such that adherence to power among familiar dyads would positively predict collective cheating to a greater extent than among stranger dyads.

\section{Method}

Participants. Ninety students in the social sciences faculty of a French-speaking Swiss university, with a mean age of 23.81 $(S D=3.93)$, participated in this study. This sample consisted of 42 male and 48 female students. Participation was voluntary and all students present participated.

Procedure. The experiment was carried out in the context of three different non-first-year university classes all within the Faculty of Social Sciences (bachelor level: sports pedagogy $(N=22)$ and sociology $(N=42)$; masters level: sports tourism $(N=26))$. In-group familiarity was treated as an experimental condition. In each class students were first asked to organize themselves into dyads, either with someone they knew reasonably well (familiar condition, $N=48$ ) or with someone they did not know (stranger condition, $N=42$ ). This produced in total 21 dyads who did not know each other and 24 who did. Once organized into their groups, students filled in a questionnaire measuring their individual values. Following this, they carried out a short task the aim of which was to reinforce the salience of in-group identification-that is, closeness and social identity in the familiar condition and separateness and individual identity in the stranger condition. Participants were asked to communicate during two minutes between them in order to produce, in the familiar condition, a list of five things they had in common, and, in the stranger condition, a list of five ways in which they were different from each other. Following this, students were informed that they were to carry out a spatial reasoning exercise in which they would attempt to reproduce six geometric figures without lifting their pencil off the page and retracing any one line more than once within a fixed time limit (Pulfrey \& Butera, 2013). The principle behind solving these exercises is a fundamental principle in math developed by Leonhard Euler in 1736 and applied in the Seven Bridges of Könisberg problem. For each question participants had a practice space and then a space in which to draw the figure if they had succeeded in working out how to produce it respecting the constraints. Dyads were asked to work as a team. The exercise was presented as a class competition and students were informed that the results would be published in class, to mimic the competitive atmosphere typical of exams in which students are likely to cheat (Pulfrey \& Butera, 2013). Participants were given 8 min to complete the six exercises and then were asked to fill in a form per group affirming whether they had succeeded in reproducing the figure or not. As three of the figures, while ostensibly no more difficult than the others, could not be drawn without lifting their pencil off the page, it was possible to detect groups who cheated.

Data analysis procedure. We carried out analyses in two stages. First, we tested the impact of the experimental manipulation of familiarity on the measure of benevolence. This constituted a sort of individual-level manipulation check. We expected that in the familiar condition individuals' adherence to benevolent ingroup loyalty would be higher than in the stranger condition as individuals had self-selected in dyads with someone they knew and a sense of in-group cohesion had been primed by the finding points in common exercise. In our first set of analyses, we regressed individual adherence to benevolence values on the familiarity versus nonfamiliarity condition. As students came from different classes, we included class as a control variable and also gender, as research has shown that women have a relatively higher concern 
and responsibility for others' well-being than men (Beutel \& Marini, 1995) and preliminary analyses revealed a gender difference in adherence to benevolence values in the sample with females valuing benevolence more than males, $B=0.29, F(1$, $89)=5.11, p=.03, \eta^{2}=.05$. As students had been grouped into dyads, we controlled for group-level effects by using the Mundlak fixed effects procedure and entering dyad as a dummy variable (Mundlak, 1978). This gave us four terms in the equation: experimental condition, gender, class, and dyad.

Second, we tested the impact of the interaction between the experimental manipulation and adherence to power values on cheating. We used a relative measure of power, as this is argued to have the potential to interact with contextual variables in the prediction of behavior as well as attitudes (Schwartz, 2006). As gender composition of groups has been associated with intragroup relations (Randel, 2002), we controlled for the gender composition of the dyads with orthogonal contrasts. The first contrast grouped the all-girls $(N=36)$ and mixed dyads $(N=28)$ both coded -1 in comparison with the all-male groups $(N=26)$ coded 2 . The second contrast compared the two types of groups with girls (mixed coded 1 and all girls coded -1 ). We also controlled for the class they were in, creating two orthogonal contrasts. The first contrast grouped the two bachelor classes together coded -1 in comparison with the masters class coded 2, and the second contrast compared the two bachelor classes (sociology coded -1 and sports pedagogy coded 1). The model thus included the experimental condition familiarity versus nonfamiliarity, dyad mean power adherence, the interaction between the two, and the gender and class contrasts as control variables, making seven terms in total. We carried out regression analyses using a Poisson regression with the number of times the dyad cheated as the dependent variable (Pulfrey \& Butera, 2013).

\section{Measures.}

Values. For time reasons, the short version SSVS-4 (Beierlein, Davidov, Cieciuch, Rammstedt, \& Schwartz, 2014) of the French version of the refined values survey was used. This version included a three-item scale of benevolence ("It is important to him/her to be a dependable and trustworthy friend" [benevolencedependability]; "It is important to him/her to help the people dear to him/her" [benevolence-caring]; and "It is important to him/her that all his friends and family can rely on him completely" [benevolence-dependability]; $\alpha=.73$ ). This was modified from the SSVS-4 in order to include two benevolence-dependability items rather than uniquely two benevolence-caring items, as in the context of academic collusion the benevolence-dependability construct appeared to be more relevant (cf. Study 3). This version also included a two-item scale of power ("It is important to him/her to be the one who tells others what to do;" "It is important to him/her to be rich;" $\alpha=.69$ ). Participants indicated on a scale going from
1 (not at all like me) to 7 (very much like me) the degree to which they felt they were like the person described in the question. A principal component analysis carried out with just the benevolence and power items confirmed the presence of two separate factors, explaining $71.67 \%$ of total variance and with loadings of each item on their respective factor no lower than .8 . We calculated a mean score per dyad of power value adherence using the Stata xtset command. Then, in order to create the relative power value score for the interaction, we calculated the mean dyad value score (all 10 values) and subtracted this from the raw dyad power score. We did not have problems with outliers or abnormal distributions. Descriptive statistics are presented in Table 6 .

Collective cheating behavior. We adapted the measure of cheating behavior developed by Pulfrey and Butera (2013) as the outcome of a collective behavior. In order to qualify as cheaters, the dyad had to have filled in the answer space reserved for successfully resolved puzzles and affirmed that they had solved the puzzle, in at least one puzzle out of the three impossible ones.

\section{Results}

Results of the first regression analysis revealed a positive effect of familiarity on participant adherence to benevolence values, $B=$ $1.06, F(1,86)=12.18, p=.001, \eta^{2}=.10$, with participants in the familiarity condition valuing benevolence more than those in the nonfamiliarity condition. We also tested the same model on individual adherence to power values and found no significant effects. No other significant effects appeared except for the dummy grouplevel variable, which corresponds to group membership (see Figure 3).

Our second set of analyses focused on cheating behavior. Descriptive analyses revealed that overall seven dyads cheated $(15.56 \%)$. In the familiar condition six dyads cheated (25\%), while only one dyad $(4.76 \%)$ cheated in the stranger condition. The regression analysis tested the impact of the interaction between the familiarity variable and relative adherence to power values on collective cheating. Results revealed-a positive main effect of familiarity on cheating, $B=19.09, S E=1.17, z=16.27, p<$ $.001, \eta^{2}=.31,95 \%$ CI [16.79, 21.39], showing that familiar dyads cheated more than stranger dyads. There was also a main effect of group-level power on collective cheating, $B=15.84$, $S E=1.07$, $z=14.77, p<.001, \eta^{2}=.30,95 \%$ CI [13.74, 17.94], and there was a positive effect of the predicted interaction between familiarity and adherence to power values, $B=-18.00, S E=1.22$, $z=-14.73, p<.001, \eta^{2}=.18,95 \%$ CI $[-20.36,-15.57]$. There was also a main effect of gender, $B=1.14, S E=0.35, z=3.32$, $p=.001, \eta^{2}=.09,95 \%$ CI $[0.47,1.82]$ with all male groups cheating more than all female or mixed.

Table 6

Study $4(N=90)$ : Descriptive Statistics

\begin{tabular}{lrrrrr}
\hline \multicolumn{1}{c}{ Variables } & \multicolumn{1}{c}{$M$} & \multicolumn{1}{c}{$S D$} & \multicolumn{1}{c}{ Range } & $(2)$ & $(3)$ \\
\hline Individual benevolence values (1) & 6.43 & .63 & $4.33-7.00$ & -.16 & $-.35^{\text {******}}$ \\
Individual power values (2) & 3.96 & 1.27 & $1.00-6.50$ & - & $.74^{* * * * *}$ \\
Group-level relative power values (3) & -1.45 & .96 & $-3.13-.83$ & - & - \\
\hline
\end{tabular}

${ }_{* * * *} p<.001$. 


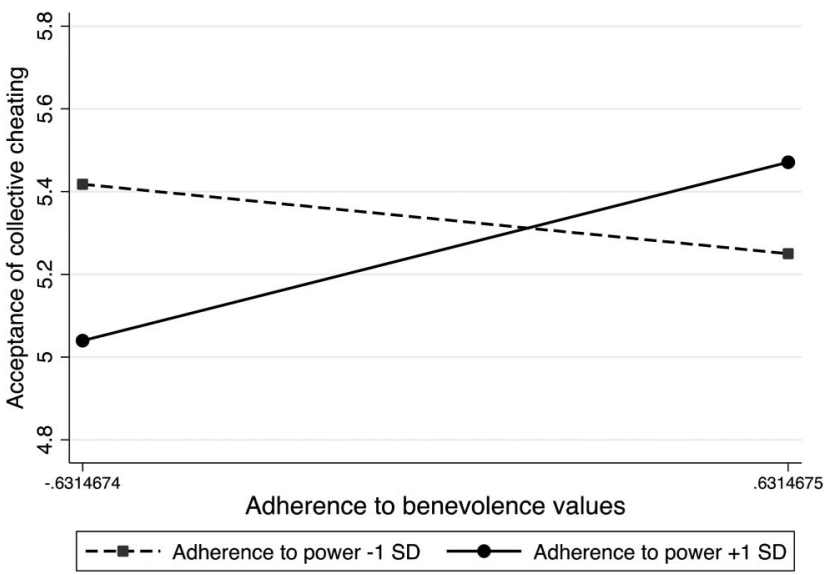

Figure 3. Study 3: Interaction between adherence to benevolencedependability values and adherence to power-dominance values.

Analysis of simple effects, run with a linear regression model because of lack of convergence of the Poisson model in the stranger condition, showed that, while adherence to power values did not significantly predict collective cheating in the stranger condition, $B=0.22, F(1,38)=1.66$, $n s$, it positively predicted collective cheating in the familiar condition, $B=0.73, F(1,38)=$ $30.69, p<.001, \eta^{2}=.49,95 \%$ CI $[0.45,0.1 .01]$. Results are presented in Figure 4.

Once again, because Study 4 has a relatively small sample size with respect to the model complexity (i.e., $k$ predictors), we went through another robustness check in order to verify that the interaction effect was not simply due to chance by running two more Monte-Carlo simulations. We used exactly the same process as in Study 2.

Results revealed that whereas the interaction of relative dyad adherence to power values and dyad familiarity in the random model had no more than a 5\% chance of producing a significant effect on the dependent variable, in the actual model, the interaction of these two variables showed a $97 \%$ probability of significance These results indicate that this is likely to be a robust effect despite the small sample size.

\section{Discussion}

In Study 4 we see first that, within a class context, students in work groups who know each other and for whom the points group members have in common are made salient, do attach more importance to individual values of benevolence than those in work groups with strangers with whom differences are accentuated. This first finding confirms the relevance of the experimental manipulation and shows that a context-specific priming of state-value adherence can be achieved. Second, we find that within an academic context in which competition is salient, familiarity between group members encourages collective cheating behavior, when compared with groups composed of strangers. We also see that relative adherence to power values predicts collective cheating among dyad members who know each other but not among dyad members who are not familiar with each other. This confirms the results of Study 3 with actual behavior in interacting dyads.
Additionally, we see again a gender effect, with groups with male students cheating more than female students.

\section{General Discussion}

The aim of this research has been to step outside the vast arena of research on individual cheating and learn more about the relatively unexplored territory of collective cheating, that is to say academic dishonesty carried out with the collusion of the in-group. We hypothesized that when competition is salient in one form or another, relative prioritization of benevolence values with their focus on in-group loyalty will positively predict more positive attitudes toward collective forms of cheating than individual cheating. Four studies provided a range of support for this hypothesis using variety of diverse methods. This is a powerful argument for the core validity of the basic finding and avoids the risk of creating one unique methodological approach, which, if invalidated, potentially renders many follow-up studies also invalid (see Sturm \& Antonakis, 2015 for an example with power priming).

Results of Study 1 revealed that relative adherence to benevolence values positively predicted acceptance of acts of collective cheating, in a condition in which participants were presented with a vision of society as fundamentally competitive in nature, whereas in a condition portraying society as cooperative and in the control condition, no significant effects were observed. These effects did not emerge for individual cheating. The fact that benevolence value adherence predicted acts of collective cheating and did not predict acts of individual cheating also indicates external discriminant validity in the collective cheating and individual cheating scales. In addition, neighboring universalism values, characterized by their focus on universal as opposed to in-group well-being, did not predict collective cheating either as a main effect or in interaction with perceived societal competition, a finding that reinforces the validity of the demarcation between these two types of self-transcendence values.

Results of Study 2 indicated that, within the resolutely competitive context of an end-of-year selective examination, relative adherence to benevolence values predicted greater degrees of

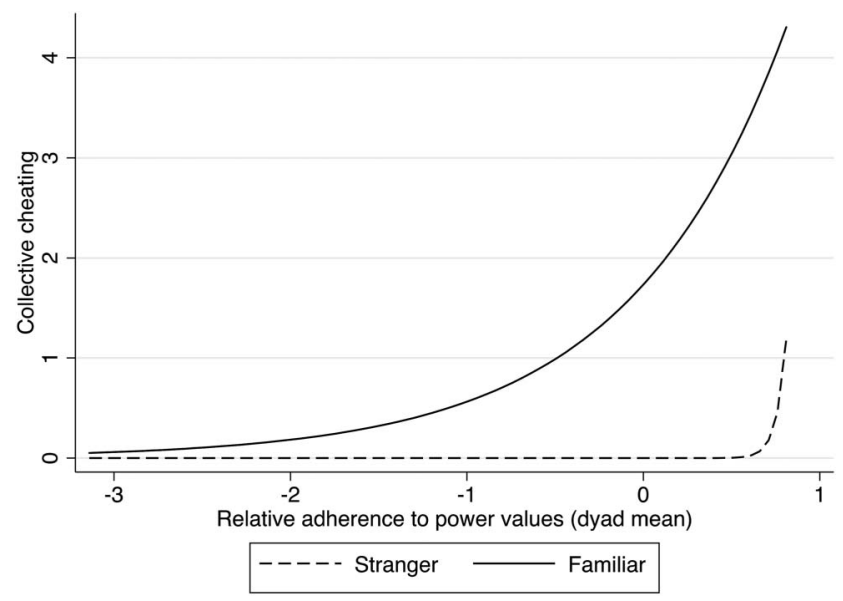

Figure 4. Study 4: Interaction between adherence to power values and experimental condition: dyad partners who know each other (familiar) versus dyad partners who do not know each other (stranger). 
moral disengagement toward acts of collective than individual cheating as described in vignettes. This reinforces the findings of Study 1 by showing that, when holding competition constant, relative adherence to benevolence values is specifically related to collective as opposed to individual cheating.

Study 3, as well as introducing the value type nuances of the recent refined model of individual values, examined the general hypothesis from the more intrapersonal angle of adherence to benevolence values in combination with adherence to power values. This allowed us to examine the relation between in-group loyalty and chronic, ongoing perceptions of a competitive environment, as the adoption of power values is underlain by the implicit perception of the social environment as one in which competition is present. Study 3 results indicated that simultaneous adherence to benevolence-dependability, in other words in-group loyalty values, and power values significantly predicted acceptance of collective cheating but not individual cheating. The use of Schwartz et al.'s (2012) refined scale of individual values makes it possible to fine-tune the precise character of the elements that contribute to predict collective cheating in the context of academic cheating. Results indicated that the more practical group contribution that issues from being a dependable, trustworthy group member was more pertinent than the more emotive devotional aspect of benevolence-caring.

Finally, in Study 4, we examined the role of familiarity with group partners, which, as we observed, renders benevolence values more contextually salient, in cheating behavior. As predicted, we found that familiarity encouraged collective cheating, and that this effect was accentuated by the degree to which team members were power-hungry. These results reinforce the work on in-group favoritism of Tajfel and Turner (1986) as well as Brewer (1999), showing that in-group familiarity is indeed related to the valuing of loyalty and also to resolutely unethical behaviors.

\section{Contribution and Integration With Other Theories}

All in all, we hope to provide a new and valuable insight into academic cheating. First, we distinguish between cheating in its individual and collective forms, aiming to contribute to define what constitutes collective cheating; second, we provide potential understanding of some reasons for its occurrence, introducing the role of individual values in interaction with social context.

A first and very important contribution of this work is to distinguish between individual and collective cheating. Research on group forms of unethical behavior is still in its infancy (see Weisel \& Shalvi, 2015) and, to our knowledge, very little research has focused on the distinction between individual and collective cheating, despite the fact that it is central to understanding the upstream motivational drives that encourage individuals and groups to cheat. While cheating research has traditionally focused on the individuals who cheat for their own individual gain (McCabe \& Treviño, 1997; Whitley, 1998), collective cheating for shared gain is a reality even in relatively individualistic contexts, as the Harvard example (Perez-Pena, 2013) shows. Anecdotal evidence implies that the same applies, not surprisingly, to collective cultural contexts (Lewicka, November, 2014. Personal communication.).

Furthermore, collective cheating is interesting not only because it is current practice in a range of cultural contexts, but also because of its much more dubious moral status, compared with the much more clear-cut, universally condemned nature of individual cheating. Both evolutionary theory (Boehm, 2012; Wilson, 2012; Sloan Wilson, 2002) and moral foundations theory (Haidt, 2012) affirm that in-group loyalty, as manifested in supporting the wellbeing of one's key group, which will in turn support one's own wellbeing, can indeed be considered a form of moral behavior. This potential to consider in-group loyalty as moral and potentially more moral than other types of morality is highly significant as it allows us to understand how it can become possible for people to fully rationalize and morally sanction via in-group loyalty, behavior that is fundamentally unethical from another, that is to say fairness and/or care.

A second contribution of this research is to understand why collective cheating may occur, introducing individual values and their relation with the social context as potential predictors of collective cheating. This is important firstly as individual values are argued to be a result of socialization and constitute the higherorder life goals (Schwartz, 1992) that are directly associated with students' achievement goals as well as motivation for studying (Pulfrey \& Butera, 2013). As such, research relating individual values to cheating carries on the longstanding tradition of research on student motivation and cheating (Anderman et al., 1998; Anderman \& Danner, 2008; Anderman \& Murdock, 2007; Murdock et al., 2001, 2004). Second, the role of social context, particularly that of a competitive, performance-oriented environment, also builds on a solid body of educational research linking competitive contexts to cheating (Anderman \& Midgley, 2004; Murdock et al., 2004). Third, the emphasis on the interaction between the individual factors and the social context also furthers the development of a well-established lineage of educational research, in which individual traits such as work ethic, goal-orientation, or motivation interact with an aspect of the environment to produce cheating (Corcoran \& Hankey, 1989; Eisenberger \& Shank, 1985).

From an applied perspective, this work also constitutes a useful contribution as benevolence, with its widespread status as a highly moral value, is promoted widely both in the media (see e.g., Keiningham \& Aksoy, 2009) and in socialization practices (Schwartz \& Butenko, 2014). In itself, this is well and fine. However, the promotion of benevolence values within a social or societal context that simultaneously promotes values of competition and self-enhancement may indeed produce the unintended and deleterious consequences of pro ingroup collective cheating. In college life, an example of this may be found in the higher incidence of cheating reported within fraternity and sorority associations (McCabe \& Bowers, 2009).

The present results also encourage us to reconsider the implications of work such as that of McCabe and Treviño (1993), who showed that creating an Honor Code, which involves responsibility to the institution as whole, reduces in-house cheating. However, while that research was only concerned with individual cheating, the present research raises the sticky question of whether an honor code that heavily emphasized institutional loyalty could conceivably encourage pro-institution collective cheating in interinstitutional contexts. In-group loyalty and high-stakes interinstitutional competition might even explain cases of teacher cheating to help students succeed in national exams (Espinoza, 2015). 


\section{Limitations}

However, and here we move on to the first limitation of this set of studies. Much work remains to be done to develop further ways of examining collective cheating. These could take into account the differences between collective versus individual cheating in course work versus exams, the relative degree of seriousness of the offense and the role of altruistic cheating within the collective cheating framework. In addition, although we would argue for the robustness of the general effect, having assessed it in four different ways, using three types of experimental approach and three different dependent variables, more work into boundary conditions, such as gender and collective cheaters' perceptions of competition is required. A further useful development will be to examine the impact of student adherence to other values such as conformity versus self-direction on collective cheating behavior, as well as the interaction between different value types.

The adaptation of Shu et al.'s (2011) measure of moral disengagement in Study 2 and the use of a CFA with a small sample size could also be considered as methodological limitations, although Wolf, Harrington, Clark, and Miller (2013) showed evidence that a one latent factor model with six indicators and loadings of .65 only requires a sample of 60 to be valid (see also Bastardoz \& Antonakis, 2014, 2016). However, as a balance to these statistical concerns, the consistency of the results across four studies using different methods strengthens confidence in the findings.

A third and associated limitation comes in the small sample size in Studies 2 and 4. Using Monte-Carlo simulation techniques has enabled us to have a good degree of confidence as to the robustness of the effects reported, despite small sample size. However, this limitation sends out a clarion call for replication with larger, diverse samples. Nevertheless, it is worth noting that this limitation emerges from the necessity, we believe, of carrying out academic cheating-related surveys and experimental work as much as possible within the ecologically sound environment of the classroom. While experimental work on cheating in laboratories expunges results of real-life error and variance, it also removes many of the contextual cues, triggers and stakes that can kick in to motivate in situ academic cheating. Research on collective cheating and the contexts which encourage it can also be enriched is by extending our understanding of the types of competition that trigger the benevolence-collective cheating phenomenon. We have found the effect with representations of macrosocietal competition as well as internalized competition in the form of adherence to power-dominance values.

However, future research should find out more about the ingroup loyalty effect within different institutional contexts, such as team-work within competitive classrooms and organizations, multi-unit businesses that set up competition between branches, inter-organizational competition within a highly competitive sector such as finance and banking. More precise questions could address the impact of the way in which competition is structured on collective cheating. For example, would benevolence values still predict collective cheating within the context of a one-winnertake-all competitive environment such as an award, or in the context of a strict numerus clausus, such as entry to Ivy League universities (see Pope, 2003)? In addition, future research could fruitfully examine whether content areas, prior achievement levels, classroom goal structures, gender composition of groups and grade levels impact collective cheating and how. For example, applying Anderman and Midgley's (2004) analysis of classroom goals and cheating in middle and high school specifically to collective cheating would provide valuable information on both age and classroom context and interactions between the two.

A further limitation of Studies 1-3 is the relatively low reliability of the measures of benevolence values. While it is beyond the scope of this article to investigate in depth the reasons for this, the relatively central space within the circumplex model of individual values that benevolence values consistently occupy (Schwartz \& Butenko, 2014) indicates that whatever other values people adhere to, benevolence values will hold a relatively important place in their overall values scheme. Support for family and friends is a human universal that will feature to a certain extent even in relatively individualistic contexts (Schwartz, 2007b) and is morally valued (Schwartz, 2007a). As such it is in line with our presentation of benevolence values as conceptually close to the universally approved in-group loyalty. One potential consequence of this phenomenon, however, is the potential for large amounts of noise or error within the measurement of benevolence as people may adhere to it for different reasons and social desirability bias may be present.

Finally, it would be of significant interest to extend this work with greater precision in the definition of the in-group. We have worked primarily with the familiar in-group that is salient in school and university. However, nationality or ethnic loyalties among students, particularly minority students and students in an international setting, as well as the family constitute other highly salient in-groups for students. Exploring collective cheating in these domains could not only refine our knowledge of the what and why of collective cheating, but also bring in additional issues such as time-lags in cheating-related reciprocal altruism as well as the potential impact of cross-cutting group identities.

\section{Conclusion}

Benevolence values are central values to human existence and adhered to worldwide, whether in relatively individualistic or collectivist cultures (Schwartz, 2007b) and loyalty to close ones is routinely promoted as the most important form of morality (Willsher, 2012). Group work with friends is encouraged in many academic settings. Parallel to this, while teachers may not explicitly encourage competition within their classes, the school and university environment is by no means free from the pressures of competition, explicit as in trophies, prizes, awards, or preparation for college or job applications, or implicit as in societal pressure to "do well" or already internalized values of power, influence, wealth, and public image. As cheating expert Donald McCabe says "I don't think there's any question that students have become more competitive, under more pressure, and, as a result, tend to excuse more from themselves and other students, and that's abetted by the adults around them" (Pérez-Pena, 2012b, p. 1). To quote one of the high-achieving high school students in Pope's (2003, p. 32) study: "To get into an Ivy. That's all I can think about . . . to get in and become a successful $\$ 500,000$-a-year doctor or engineer or whatever it is I want to be. . . . I have to get accepted." Students who value benevolence may thus be torn between the imperative of success and loyalty to their friends and one neat way around this form of dissonance may indeed be engagement in collective cheat- 
ing, where the unethical aspect of cheating is seen through the muddied lens of helping friends as well as themselves.

This situation is exacerbated by the cloud of moral ambiguity of which seems to surround collaboration in many students' minds about how much is tolerated and when (Chapman \& Monahan, 2012; Finder, 2007). Harvard has recently introduced a paragraph on collective cheating in its handbook for students (Harvard University FAS Student Handbook, 2017) and as, Pérez-Peña (2014, p. 4) affirms "schools need to talk much more about honesty, because students' grasp of what constitutes cheating is weak." This highlights the critical importance of understanding more about how adherence to such well-accepted moral values as in-group loyal support can, in certain conditions, lead to justifying unethical behavior. Research has to date prioritized investigation of individual cheating in academic settings. Now is the time to expand our horizons and understand more about how students cheat together.

\section{References}

Allport, G. (1954). The nature of prejudice. Reading, MA: Addison Wesley.

Anderman, E. M., \& Danner, F. (2008). Achievement goals and academic cheating. Revue Internationale de Psychologie Sociale, 21, 155-180.

Anderman, E. M., Griesinger, T., \& Westerfield, G. (1998). Motivation and cheating during early adolescence. Journal of Educational Psychology, 90, 84-93. http://dx.doi.org/10.1037/0022-0663.90.1.84

Anderman, E. M., Maehr, M. L., \& Midgley, C. (1999). Declining motivation after the transition to middle school: Schools can make a difference. Journal of Research and Development in Education, 32, 131-147.

Anderman, E. M., \& Midgley, C. (2004). Changes in self-reported academic cheating across the transition from middle school to high school. Contemporary Educational Psychology, 29, 499-517.

Anderman, E. M., \& Murdock, T. (2007). Psychology of academic cheating. San Diego, CA: Elsevier. http://dx.doi.org/10.1016/B978012372541-7/50002-4

Antonakis, J., \& House, R. J. (2014). Instrumental leadership: Measurement and extension of transformational-transactional leadership theory. The Leadership Quarterly, 25, 746-771. http://dx.doi.org/10.1016/j .leaqua.2014.04.005

Athanasou, J. A., \& Olasehinde, O. (2002). Male and female differences in self-report cheating. Practical Assessment, Research \& Evaluation. Retrieved from http://PAREonline.net/getvn.asp?v $=8 \& \mathrm{n}=5$

Axelrod, R., \& Hamilton, W. D. (1981). The evolution of cooperation. Science, 211, 1390-1396. http://dx.doi.org/10.1126/science.7466396

Bahr, A. (2014). When the college admissions battle starts at age 3. The New York Times. Retrieved from https://www.nytimes.com/2014/07/30/ upshot/when-the-college-admissions-battle-starts-at-age-3.html

Baines, E., Blatchford, P., \& Chowne, A. (2007). Improving the effectiveness of collaborative group work in primary schools: Effect on Science attainment. British Educational Research Journal, 33, 663-680. http:// dx.doi.org/10.1080/01411920701582231

Bandura, A. (2002). Selective moral disengagement in the exercise of moral agency. Journal of Moral Education, 31, 101-119. http://dx.doi .org/10.1080/0305724022014322

Bastardoz, N., \& Antonakis, J. (2014, January). Sample size requirement for unbiased estimation of structural equation models: A Monte Carlo study. Academy of Management Proceedings, 2014, 13405. http://dx.doi .org/10.5465/AMBPP.2014.13405abstract

Bastardoz, N., \& Antonakis, J. (2016, January). How should the fit of structural equation models be judged? Insights from Monte Carlo simulations. Academy of Management Proceedings, 2016, 12634. http://dx .doi.org/10.5465/AMBPP.2016.12634abstract
Beck, J. (1999). Makeover or takeover? The strange death of educational autonomy in neo-liberal England. British Journal of Sociology of Education, 20, 223-238. http://dx.doi.org/10.1080/01425699995425

Beierlein, C., Davidov, E., Cieciuch, J., Rammstedt, B., \& Schwartz, S. H. (July, 2014). Schwartz Values Short Scale (SVSS-4)-An economical measurement tool for cross-cultural research. Paper presented at the 22nd Congress of the International Association for Cross-Cultural Psychology, Reims, France.

Bernardi, R. A., Metzger, R. L., Bruno, R. G. S., Hoogkamp, M. A. W., Reyes, L. E., \& Barnaby, G. H. (2004). Examining the decision process of students' cheating behaviour: An empirical study. Journal of Business Ethics, 50, 397-414. http://dx.doi.org/10.1023/B:BUSI.0000025039 47788.c2

Beutel, A. M., \& Marini, M. M. (1995). Gender and values. American Sociological Review, 60, 436-448. http://dx.doi.org/10.2307/2096423

Blatchford, P., Kutnick, P., Baines, E., \& Galton, M. (2003). Toward a social pedagogy of classroom group work. International Journal of Educational Research, 39, 153-172. http://dx.doi.org/10.1016/S08830355(03)00078-8

Boehm, C. (2012). Moral origins: the evolution of virtue, altruism and shame. New York, NY: Basic Books.

Brewer, M. B. (1979). In-group bias in the minimal intergroup situation: A cognitive-motivational analysis. Psychological Bulletin, 86, 307-324. http://dx.doi.org/10.1037/0033-2909.86.2.307

Brewer, M. B. (1999). The psychology of prejudice: Ingroup love or outgroup hate? Journal of Social Issues, 55, 429-444. http://dx.doi.org/ $10.1111 / 0022-4537.00126$

Brewer, M. B., \& Silver, M. (1978). Ingroup bias as a function of task characteristics. European Journal of Social Psychology, 8, 393-400. http://dx.doi.org/10.1002/ejsp.2420080312

Bushway, A., \& Nash, W. R. (1977). School cheating behavior. Review of Educational Research, 47, 623-632. http://dx.doi.org/10.3102/ 00346543047004623

Carey, T. (2014). We need to stop pushing our kids. The Guardian. Retrieved from https://www.theguardian.com/lifeandstyle/2014/oct/04/ we-need-stop-pushing-our-kids-parents

Chapman, B., \& Monahan, R. (2012). Cheating scandal involving over 50 kids rocks Stuyvesant High. NY Daily News. Retrieved from http://www .nydailynews.com/new-york/education/stuyvesant-high-sch...bannedcell-phone-distribute-answers-classmates-article-1.1102124

Charles, J. (2014). The hardest job for graduates? Finding a job. Retrieved from https://www.theguardian.com/money/2014/aug/30/hardest-job-forgraduates

Chatzisarantis, N. L., \& Biddle, S. J. (1998). Functional significance of psychological variables that are included in the Theory of Planned Behaviour: A Self-Determination Theory approach to the study of attitudes, subjective norms, perceptions of control and intentions. European Journal of Social Psychology, 28, 303-322.

Clarke, J. (2004). Dissolving the public realm: The logics and limits of neo-liberalism. Journal of Social Policy, 33, 27-48. http://dx.doi.org/10 1017/S0047279403007244

Cohen, T. R., Montoya, R. M., \& Insko, C. A. (2006). Group morality and intergroup relations: Cross-cultural and experimental evidence. Personality and Social Psychology Bulletin, 32, 1559-1572. http://dx.doi.org/ $10.1177 / 0146167206291673$

Cook, P. J., \& Frank, R. H. (2010). The winner-take-all society: Why the few at the top get so much more than the rest of us. New York, NY: Random House.

Corcoran, K. J., \& Hankey, J. (1989). Cheating following success and failure in heavy and moderate social drinkers. The Journal of General Psychology, 116, 311-316. http://dx.doi.org/10.1080/00221309.1989 .9917765

Davis, S. F., Grover, C. A., Becker, A. H., \& McGregor, L. N. (1992). Academic dishonesty: Prevalence determinants, techniques, and punish- 
ments. Teaching of Psychology, 19, 16-20. http://dx.doi.org/10.1207/ s15328023top1901_3

Davy, J. A., Kincaid, J. F., Smith, K. J., \& Trawick, M. A. (2007). An examination of the role of attitudinal characteristics and motivation on the cheating behavior of business students. Ethics \& Behavior, 17, 281-302. http://dx.doi.org/10.1080/10508420701519304

Deci, E. L., \& Ryan, R. M. (1987). The support of autonomy and the control of behavior. Journal of Personality and Social Psychology, 53, 1024

Deutsch, M. (1979). Education and distributive justice: Some reflections on grading systems. American Psychologist, 34, 391-401. http://dx.doi.org/ 10.1037/0003-066X.34.5.391

Eisenberger, R., \& Shank, D. M. (1985). Personal work ethic and effort training affect cheating. Journal of Personality and Social Psychology, 49, 520-528. http://dx.doi.org/10.1037/0022-3514.49.2.520

Elliot, A. J., Chirkov, V. I., Kim, Y., \& Sheldon, K. M. (2001). A cross-cultural analysis of avoidance (relative to approach) personal goals. Psychological Science, 12, 505-510.

Elliot, A. J., \& Moller, A. C. (2003). Performance-approach goals: Good or bad forms of regulation? International Journal of Educational Research, 39, 339-356. http://dx.doi.org/10.1016/j.ijer.2004.06.003

Elliot, A. J., Shell, M. M., Henry, K. B., \& Maier, M. A. (2005). Achievement goals, performance contingencies, and performance attainment: An experimental test. Journal of Educational Psychology, 97, 630.

Elliot, L. (2017). Middle classes in crisis, IMF's Christine Lagarde tells Davos. Retrieved from https://www.theguardian.com/business/2017/jan/ 18/middle-classes-imf-christine-lagarde-davos-2017-joe-biden

Ericson, R., Barry, D., \& Doyle, A. (2000). The moral hazards of neoliberalism: Lessons from the private insurance industry. Economy and Society, 29, 532-558. http://dx.doi.org/10.1080/03085140050174778

Espinoza, J. (2015, June). Teachers routinely help pupils cheat, investigation reveals. The Telegraph. Retrieved from http://www.telegraph.co.uk/ education/educationnews/11674136/Teachers-routinely-help-pupilscheat-investigation-reveals.html

Finder, A. (2007). 34 Duke business students face discipline for cheating. The New York Times. Retrieved from http://www.nytimes.com/2007/05/ 01/us/01duke.html

Franklyn-Stokes, A., \& Newstead, S. E. (1995). Undergraduate cheating; who does what and why? Studies in Higher Education, 20, 159-172. http://dx.doi.org/10.1080/03075079512331381673

Fu, F., Tarnita, C. E., Christakis, N. A., Wang, L., Rand, D. G., \& Nowak, M. A. (2012). Evolution of in-group favoritism. Nature Scientific Reports, 2, 460. http://dx.doi.org/10.1038/srep00460

Gallant, T. B., \& Drinan, P. (2006). Organizational theory and student cheating: Explanation, responses, and strategies. The Journal of Higher Education, 77, 839-860. http://dx.doi.org/10.1080/00221546.2006 .11778946

Giacalone, R., \& Thompson, K. (2006). Business ethics and social responsibility education: Shifting the worldview. Academy of Management Learning \& Education, 5, 266-277. http://dx.doi.org/10.5465/AMLE .2006 .22697016

Gilligan, C. (1982). In a different voice: Psychological theory and women's development. Cambridge, MA: Harvard University Press.

Graham, J., Haidt, J., \& Nosek, B. A. (2009). Liberals and conservatives rely on different sets of moral foundations. Journal of Personality and Social Psychology, 96, 1029-1046. http://dx.doi.org/10.1037/a0015141

Haidt, J. (2012). The righteous mind: Why good people are divided by politics and religion. New York, NY: Pantheon.

Haines, V. J., Diekhoff, G. M., Labeff, E. E., \& Clark, R. E. (1986). College cheating: Immaturity, lack of commitment, and the neutralizing attitude. Research in Higher Education, 25, 342-354. http://dx.doi.org/ 10.1007/BF00992130

Harackiewicz, J. M., Barron, K. E., Tauer, J. M., \& Elliot, A. J. (2002). Predicting success in college: A longitudinal study of achievement goals and ability measures as predictors of interest and performance from freshman year through graduation. Journal of Educational Psychology, 94,562

Harrison, P. A., \& Narayan, G. (2003). Differences in behavior, psychological factors, and environmental factors associated with participation in school sports and other activities in adolescence. The Journal of School Health, 73, 113-120. http://dx.doi.org/10.1111/j.1746-1561.2003 .tb03585.x

Hartocollis, A. (2016). Greater competition for college places means higher anxiety, too. The New York Times. Retrieved from https://www.nytimes .com/2016/04/21/us/greater-competition-for-college-places-meanshigher-anxiety-too.html

Harvard University Faculty of Arts and Sciences Student Handbook (2017). Plagiarism and collaboration. Retrieved from http://static.fas .harvard.edu/registrar/ugrad_handbook/2009_2010/chapter2/plagiarism .html

Hildreth, J. A. D., Gino, F., \& Bazerman, M. (2016). Blind loyalty? When group loyalty makes us see evil or engage in it. Organizational Behavior and Human Decision Processes, 132, 16-36. http://dx.doi.org/10.1016/ j.obhdp.2015.10.001

Hrabak, M., Vujaklija, A., Vodopivec, I., Hren, D., Marusić, M., \& Marusić, A. (2004). Academic misconduct among medical students in a post-communist country. Medical Education, 38, 276-285. http://dx.doi .org/10.1111/j.1365-2923.2004.01766.x

Ivywise. (2017). Admission rates. Retrieved from https://www.ivywise .com/ivywise-knowledgebase/admission-statistics/

Jacquart, P., \& Antonakis, J. (2015). When does charisma matter for top-level leaders? Effect of attributional ambiguity. Academy of Management Journal, 58, 1051-1074. http://dx.doi.org/10.5465/amj.2012 .0831

Jin, N., \& Yamagishi, T. (1997). Group heuristics in social dilemma Japanese Journal of Social Psychology, 12, 190-198.

Johnson, D. W., \& Johnson, R. (1999). Learning together and alone: Cooperative, competitive, and individualistic learning (5th ed.). Boston, MA: Allyn \& Bacon. (Original work published 1975)

Jordan, A. E. (2001). College student cheating: The role of motivation, perceived norms, attitudes, and knowledge of institutional policy. Ethics \& Behavior, 11, 233-247. http://dx.doi.org/10.1207/S15327019EB 1103_3

Kasser, T., Cohn, S., Kanner, A. D., \& Ryan, R. M. (2007). Some costs of American corporate capitalism: A psychological exploration of value and goal conflicts. Psychological Inquiry, 18, 1-22.

Keiningham, T., \& Aksoy, L. (2009). Why loyalty matters. Dallas, TX: Benbella Books Inc.

Kohlberg, L. (1976). Moral stages and moralization: The cognitivedevelopmental approach. In T. E. Lickona (Ed.), Moral development and behavior: Theory, research and social issues (pp. 31-55). Holt, NY: Rinehart and Winston.

Kurtines, W. M., \& Gewirtz, J. L. (1984). Morality, moral behavior, and moral development. New York, NY: Wiley.

Larner, W. (2000). Neoliberalism: Policy, ideology, governmentality. Studies in Political Economy, 63, 5-26. http://dx.doi.org/10.1080/19187033 2000.11675231

Larner, W., \& Craig, D. (2005). Community activism and local partnerships in Aotearoa New Zealand. Antipode, 37, 402-424. http://dx.doi .org/10.1111/j.0066-4812.2005.00504.x

Linnenbrink, E. A., \& Pintrich, P. R. (2002). Motivation as an enabler for academic success. School Psychology Review, 31, 313.

McCabe, D. L. (2005). It takes a village: Academic dishonesty \& educational opportunity. Liberal Education, 91, 26-31.

McCabe, D. L., \& Bowers, W. J. (2009). The relationship between student cheating and college fraternity or sorority membership. National Association of Student Personnel Administrators Journal, 46, 573-586. 
McCabe, D. L., \& Treviño, L. K. (1993). Academic dishonesty: Honor codes and other contextual influences. The Journal of Higher Education, $38,522-538$.

McCabe, D. L., \& Treviño, L. K. (1997). Individual and contextual influences on academic dishonesty: A multicampus investigation. Research in Higher Education, 38, 379-396. http://dx.doi.org/10.1023/A: 1024954224675

McCabe, D., \& Trevino, L. K. (2002). Honesty and honor codes. Academe, 88, 37. http://dx.doi.org/10.2307/40252118

McCabe, D. L., Treviño, L. K., \& Butterfield, K. D. (1999). Academic integrity in honor code and non-honor code environments: A qualitative investigation. The Journal of Higher Education, 70, 211-234.

McHoskey, J. W. (1999). Machiavellianism, intrinsic versus extrinsic goals, and social interest: A self-determination theory analysis. Motivation and Emotion, 23, 267-283.

Moll, J., de Oliveira-Souza, R., \& Eslinger, P. J. (2003). Morals and the human brain: A working model. Neuroreport, 14, 299-305. http://dx .doi.org/10.1097/00001756-200303030-00001

Mundlak, Y. (1978). Pooling of time-series and cross-section data. Econometrica, 46, 69-85. http://dx.doi.org/10.2307/1913646

Murdock, T. B., \& Anderman, E. M. (2006). Motivational perspectives on student cheating: Toward an integrated model of academic dishonesty. Educational Psychologist, 41, 129-145. http://dx.doi.org/10.1207/ s15326985ep4103_1

Murdock, T. B., Hale, N. M., \& Weber, M. J. (2001). Predictors of cheating among early adolescents: Academic and social motivations. Contemporary Educational Psychology, 26, 96-115. http://dx.doi.org/10.1006/ ceps. 2000.1046

Murdock, T., Miller, A., \& Goetzinger, A. (2007). Effects of classroom context on university students' judgments about cheating: Mediating and moderating processes. Social Psychology of Education, 10, 141-169. http://dx.doi.org/10.1007/s11218-007-9015-1

Murdock, T. B., Miller, A., \& Kohlhardt, J. (2004). Effects of classroom context variables on high school students' judgments of the acceptability and likelihood of cheating. Journal of Educational Psychology, 96, 765-777. http://dx.doi.org/10.1037/0022-0663.96.4.765

Muthen, L. K., \& Muthen, B. O. (2002). How to use a Monte Carlo Study to decide on sample size and determine power. Structural Equation Modeling, 9, 599-620. http://dx.doi.org/10.1207/S15328007SEM 0904_8

Newstead, S. E., Franklyn-Stokes, A., \& Armstead, P. (1996). Individual differences in student cheating. Journal of Educational Psychology, 88, 229-241. http://dx.doi.org/10.1037/0022-0663.88.2.229

Nordmo, I., \& Samara, A. (2009). The study experiences of the high achievers in a competitive academic environment: A cost of success? Issues in Educational Research, 19, 255-270.

Osterman, K. (2000). Students' need for belonging in the school community. Review of Educational Research, 70, 323-367. http://dx.doi.org/10 .3102/00346543070003323

Oxford Dictionary of English (3rd Edition). (2010). A. Stevenson (Ed.). Oxford, London: Oxford University Press

Pérez-Pena, R. (2012a, August 31). Harvard students in cheating scandal say collaboration was accepted. New York Times. Retrieved from http:// www.nytimes.com/2012/09/01/education/students-of-harvard-cheatingscandal-say-group-work-was-accepted.html

Pérez-Pena, R. (2012b, September 7). Studies find more students cheating, with high achievers no exception. New York Times. Retrieved from http://www.nytimes.com/2012/09/08/education/studies-show-morestudents-cheat-even-high-achievers.html

Pérez-Pena, R. (2013, September 16). Students accused of cheating return awkwardly to a changed Harvard. New York Times. Retrieved from http://www.nytimes.com/2013/09/17/education/students-accused-ofcheating-return-awkwardly-to-a-changed-harvard.html
Pérez-Pena, R. (2014). Best, brightest and rejected: Elite colleges turn away up to 95\%. Retrieved from https://www.nytimes.com/2014/04/09/ us/led-by-stanfords-5-top-colleges-acceptance-rates-hit-new-lows.html

Pike, G. R. (2003). Membership in a fraternity or sorority, student engagement, and educational outcomes at AAU public research university. Journal of College Student Development, 44, 369-382. http://dx.doi.org/ 10.1353/csd.2003.0031

Pope, D. (2003). Doing school: How we are creating a generation of stressed-out, materialistic, and miseducated students. London, UK: Yale University Press.

Pulfrey, C., Buchs, C., \& Butera, F. (2011). Why grades engender performance avoidance goals: The mediating role of autonomous motivation Journal of Educational Psychology, 103, 683-700. http://dx.doi.org/10 .1037/a0023911

Pulfrey, C., \& Butera, F. (2013). Why neoliberal values of selfenhancement lead to cheating in higher education: A motivational account. Psychological Science, 24, 2153-2162. http://dx.doi.org/10.1177/ 0956797613487221

Pulfrey, C., \& Butera, F. (2016). When and why people don't accept cheating: Self-transcendence values, social responsibility, mastery goals and attitudes towards cheating. Motivation and Emotion, 40, 438-454. http://dx.doi.org/10.1007/s11031-015-9530-x

Pulfrey, C., Darnon, C., \& Butera, F. (2013). Autonomy and task performance: Explaining the impact of grades on intrinsic motivation. Journal of Educational Psychology, 105, 39-57. http://dx.doi.org/10.1037/ a0029376

Pulfrey, C., Schwartz, S., Crouzevialle, M., \& Butera, F. (2017). A valuesdriven, hierarchical model of motivation and achievement goals. Manuscript in preparation.

Randel, A. E. (2002). Identity salience: A moderator of the relationship between group gender composition and work group conflict. Journal of Organizational Behavior, 23, 749-766. http://dx.doi.org/10.1002/job .163

Rettinger, D. A., Jordan, A. E., \& Peschiera, F. (2004). Evaluating the motivation of other students to cheat: A vignette experiment. Research in Higher Education, 45, 873-890. http://dx.doi.org/10.1007/s11162004-5952-0

Rose, N. (1993). Government, authority and expertise in advanced liberalism. Economy and Society, 22, 283-299. http://dx.doi.org/10.1080/ 03085149300000019

Ryan, R. M., \& Deci, E. L. (2000). Intrinsic and extrinsic motivations: Classic definitions and new directions. Contemporary Educational Psychology, 25, 54-67.

Ryan, R. M., \& Weinstein, N. (2009). Undermining quality teaching and learning: A self-determination theory perspective on high-stakes testing. Theory and Research in Education, 7, 224-233.

Ryen, A. H., \& Kahn, A. (1975). Effects of intergroup orientation on group attitudes and proxemic behaviors. Journal of Personality and Social Psychology, 31, 302-310. http://dx.doi.org/10.1037/h0076283

Schwartz, S. H. (1992). Universals in the content and structure of values: Theory and empirical tests in 20 countries. In M. Zanna (Ed.), Advances in experimental social psychology (Vol. 25, pp. 1-65). New York, NY: Academic Press.

Schwartz, S. H. (2006). Les valeurs de base de la personne: Théorie, mesures et applications [Basic personal values: Theory, measures and applications]. Revue Francaise de Sociologie, 47, 129-168. http://dx.doi .org/10.3917/rfs.474.0929

Schwartz, S. H. (2007a). Universalism values and the inclusiveness of our moral universe. Journal of Cross-Cultural Psychology, 38, 711-728. http://dx.doi.org/10.1177/0022022107308992

Schwartz, S. H. (2007b). Cultural and individual value correlates of capitalism: A comparative analysis. Psychological Inquiry, 18, 52-57. http://dx.doi.org/10.1080/10478400701388963 
Schwartz, S. H., \& Butenko, T. (2014). Values and behavior: Validating the refined value theory in Russia. European Journal of Social Psychology, 44, 799-813. http://dx.doi.org/10.1002/ejsp.2053

Schwartz, S. H., Cieciuch, J., Vecchione, M., Davidov, E., Fischer, R., Beierlein, C., . . . Konty, M. (2012). Refining the theory of basic individual values. Journal of Personality and Social Psychology, 103, 663-688. http://dx.doi.org/10.1037/a0029393

Schwartz, S. H., Melech, G., Lehman, A., Burgess, S., Harris, M., \& Owens, V. (2001). Extending the cross-cultural validity of the theory of basic human values with a different method of measurement. Journal of Cross-Cultural Psychology, 32, 519-542. http://dx.doi.org/10.1177/ 0022022101032005001

Sherif, M., Harvey, O. J., White, B. J., Hood, W. R., \& Sherif, C. W. (1961). Intergroup conflict and cooperation: The Robbers Cave experiment. Norman, OK: University Book Exchange.

Shu, L. L., Gino, F., \& Bazerman, M. H. (2011). Dishonest deed, clear conscience: Self-preservation through moral disengagement and motivated forgetting. Personality and Social Psychology Bulletin, 37, 330349. http://dx.doi.org/10.1177/0146167211398138

Sloan Wilson, D. (2002). Darwin's cathedral. Chicago, IL: University of Chicago Press. http://dx.doi.org/10.7208/chicago/9780226901374.001 .0001

Smith, A. (2006, March). Group work benefits pupils, study finds. The Guardian. Retrieved from https://www.theguardian.com/education/ 2006/mar/31/schools.uk2

Smith, K. A., Sheppard, S. D., Johnson, D. W., \& Johnson, R. T. (2005). Pedagogies of engagement: Classroom-based practices. Journal of Engineering Education, 94, 87-101. http://dx.doi.org/10.1002/j.2168-9830 .2005.tb00831.x

Statalist. (2010). Re: St: Right skewed (positive) dependent variable. Retrieved from http://www.stata.com/statalist/archive/2010-06/msg00553 .html

Stata User's Guide. Release 14. (2015). Retrieved from http://www.stata .com/manuals14/u.pdf

Sturm, R. E., \& Antonakis, J. (2015). Interpersonal power: A review, critique, and research agenda. Journal of Management, 41, 136-163. http://dx.doi.org/10.1177/0149206314555769

Tajfel, H., \& Turner, J. C. (1986). The social identity theory of intergroup behavior. In S. Worchel \& G. Austin (Eds.), Psychology of intergroup relations (pp. 7-24). Chicago, IL: Nelson-Hall.

Trivers, R. (1971). The evolution of reciprocal altruism. The Quarterly Review of Biology, 46, 35-57. http://dx.doi.org/10.1086/406755

Tsang, J. (2002). Moral rationalization and the integration of situational factors and psychological processes in immoral behavior. Review of General Psychology, 6, 25-50. http://dx.doi.org/10.1037/1089-2680.6 .1 .25

Tsui, A. S., \& Fahr, J. L. (1997). Where Guanxi matter. Relational demography and Guanxi in the Chinese context. Work and Occupations, 24, 56-79. http://dx.doi.org/10.1177/0730888497024001005

Toma, C., \& Butera, F. (2009). Hidden profiles and concealed information: Strategic information sharing and use in group decision making. Personality and Social Psychology Bulletin, 35, 793-806.
Turner, J. C. (1975). Social comparison and social identity: Some prospects for intergroup behaviour. European Journal of Social Psychology, 5, 1-34. http://dx.doi.org/10.1002/ejsp.2420050102

Tyler, K. M., Uqdah, A. L., Dillihunt, M. L., Beatty-Hazelbaker, R., Conner, T., Gadson, N., . . . Stevens, R. (2008). Cultural discontinuity: Toward a quantitative investigation of a major hypothesis in education. Educational Researcher, 37, 280-297. http://dx.doi.org/10.3102/ 0013189X08321459

Van Yperen, N. W., Hamstra, M. R., \& van der Klauw, M. (2011). To win, or not to lose, at any cost: The impact of achievement goals on cheating. British Journal of Management, 22.

Vauclair, C.-M. (2009). Desired or desirable values? Considering morality in cross-cultural value research and its implications for research and measurement. Mackenzie Business Review, 10, 60-83.

Weisel, O., \& Shalvi, S. (2015). The collaborative roots of corruption. Proceedings of the National Academy of Sciences of the United States of America, 112, 10651-10656. http://dx.doi.org/10.1073/pnas.14230 35112

Wentzel, K. R., Barry, C. M., \& Caldwell, K. A. (2004). Friendships in middle school: Influences on motivation and school adjustment. Journal of Educational Psychology, 96, 195-203. http://dx.doi.org/10.1037/ 0022-0663.96.2.195

Whitley, B. E., Jr. (1998). Factors associated with cheating among college students: A review. Research in Higher Education, 39, 235-274. http:// dx.doi.org/10.1023/A:1018724900565

Wigfield, A., \& Eccles, J. S. (2000). Expectancy-value theory of achievement motivation. Contemporary Educational Psychology, 25, 68-81. http://dx.doi.org/10.1006/ceps.1999.1015

Wildschut, T., Insko, C. A., \& Gaertner, L. (2002). Intragroup social influence and intergroup competition. Journal of Personality and Social Psychology, 82, 975-992. http://dx.doi.org/10.1037/0022-3514.82.6.975

Willsher, K. (2012, June). Jérôme Kerviel seeks to put SocGen in dock over $€ 5$ bn loss. The Guardian. Retrieved from http://www.theguardian .com/business/2012/jun/04/jerome-kerviel-launches-appeal-socgen

Wilson, E. O. (2012). The social conquest of Earth. New York, NY Liveright Publishing Corporation.

Wolf, E. J., Harrington, K. M., Clark, S. L., \& Miller, M. W. (2013) Sample size requirements for structural equation models: An evaluation of power, bias, and solution propriety. Educational and Psychological Measurement, 76, 913-934. http://dx.doi.org/10.1177/001316441 3495237

Worchel, S., Andreoli, V. A., \& Folger, R. (1977). Intergroup cooperation and intergroup attraction: The effect of previous interaction and outcome of combined effort. Journal of Experimental Social Psychology, 13, 131-140.

Yamagishi, T., Jin, N., \& Miller, A. S. (1998). In-group bias and culture of collectivism. Asian Journal of Social Psychology, 1, 315-328.

Yamagishi, T., \& Kiyonari, T. (2000). The group as the container of generalized reciprocity. Social Psychology Quarterly, 63, 116-132.

Yamagishi, T., Mifune, N., Liu, J. H., \& Pauling, J. (2008). Exchanges of group-based favors: Ingroup bias in the prisoner's dilemma game with minimal groups in Japan and New Zealand. Asian Journal of Social Psychology, 11, 196-207. 


\section{Appendix A}

\section{Study 1 - Experimental Condition Vignettes}

In the self-enhancement society condition, students read the following text:

\section{Competitive Market}

The society your studies are preparing you for is a market, which functions through competition. Economic efficiency and consumption are central-your wellbeing is enhanced by having things. The accumulation of material wealth, status, and consequently power is a worthy objective. You need to think about your individual needs and how to gain a competitive advantage in life. You are free to choose what you buy and to decide what you want to achieve in your life. For companies, financial accountability and technical rationality are paramount: Profit is the goal and the end justifies the means. Prioritizing corporate interests helps society as the wealth trickles down to create a healthy economy. Human resources are valued and rewarded to the extent that they advance company interests. As Charles Darwin said "In the struggle for survival, the fittest win out at the expense of their rivals."
In the self-transcendence society condition participants were given the same instructions and read the following text:

\section{Cooperative Community}

\begin{abstract}
The society your studies are preparing you for is a community, which functions through cooperation. Nonfinancial, human outcomes are central-your wellbeing is enhanced by self-actualization-and the generation of human happiness and life satisfaction, altruism, and transcendence is a worthy objective. You need to balance individual and community needs across generations, invest in the future and focus on living life with meaning. For companies, physical, social well-being, quality of life, and the well-being of the broader society are paramount; the betterment of people, society, and the ecological system is the goal and how you act at work counts as much as the outcome. Business is there for the good of all involved, but also to serve humanity and advance the interests of all humankind. As Martin Luther King said "We may have all come on different ships, but we're in the same boat now."
\end{abstract}

\section{Appendix B}

\section{Study 2 - Experimental Condition Vignettes}

Individual cheating - copying: "I' $m$ studying at the University of XXX. At the end of my first year, I had to take an exam that would determine whether I got into the second year or not. All the students were seated relatively close to each other. During the test, I was therefore able to see the answers of the person in front of me. That helped me to pass the exam and get into the second year."

Collective cheating-helping in-group: "I'm studying at the University of XXX. At the end of my first year, our first year, my three best friends and I had to take an exam that would determine whether we got into the second year or not. All the students were seated relatively close to each other. During the test, I was therefore able to show my paper to my friends and share my answers with them. That helped them to pass the exam and get into the second year."
Collective cheating — copying off others: "I'm studying at the University of XXX. At the end of our first year, my three best friends and I had to take an exam that would determine whether we got into the second year or not. All the students were seated relatively close to each other. During the test, we were therefore able to see the answers of the people in front of us. That helped us to pass the exam and get into the second year."

Collective cheating - copying of each other (sharing answers): "I'm studying at the University of XXX. At the end of our first year, my three best friends and I had to take an exam that would determine whether we got into the second year or not. All the students were seated relatively close to each other. During the test, we were therefore able to share our answers. That helped us to pass the exam and get into the second year."

\section{Appendix C}

\section{Study 2 - Experimental Condition 1 Vignette in French}

The French version of the first vignette is as follows: Cidessous, vous trouverez l'extrait du témoignage d'Alex, qui étudie dans cette université. Merci d'en prendre connaissance. « Je fais mes études à l'université de XXX. A la fin de ma première année, j'ai subi un examen déterminant pour ma promotion en deuxième année. Tous les étudiants étaient assis relativement proche les uns des autres. Durant l'épreuve, j'ai donc pu voir les réponses de la personne assise devant moi. Cela m'a aidé à réussir l'examen et à passer en deuxième année ».

Received August 23, 2016

Revision received October 8, 2017

Accepted October 14, 2017 